\title{
Parameterization of vertical chlorophyll $a$ in the Arctic Ocean: impact of the subsurface chlorophyll maximum on regional, seasonal, and annual primary production estimates
}

\author{
M. Ardyna ${ }^{1}$, M. Babin ${ }^{1}$, M. Gosselin ${ }^{2}$, E. Devred ${ }^{1}$, S. Bélanger ${ }^{3}$, A. Matsuoka ${ }^{1}$, and J.-É. Tremblay ${ }^{1}$ \\ ${ }^{1}$ Takuvik Joint International Laboratory, Laval University (Canada) - CNRS (France), UMI3376, Département de biologie et \\ Québec-Océan, Université Laval, Québec, Québec G1V 0A6, Canada \\ ${ }^{2}$ Institut des sciences de la mer de Rimouski, Université du Québec à Rimouski, 310 Allée des Ursulines, Rimouski, Québec \\ G5L 3A1, Canada \\ ${ }^{3}$ BORÉAS and Département de biologie, chimie et géographie, Université du Québec à Rimouski, 300 Allée des Ursulines, \\ Rimouski, Québec G5L 3A1, Canada
}

Correspondence to: M. Ardyna (mathieu.ardyna@takuvik.ulaval.ca)

Received: 4 December 2012 - Published in Biogeosciences Discuss.: 29 January 2013

Revised: 24 April 2013 - Accepted: 14 May 201 - Published: 28 June 2013

\begin{abstract}
Predicting water-column phytoplankton biomass from near-surface measurements is a common approach in biological oceanography, particularly since the advent of satellite remote sensing of ocean color (OC). In the Arctic Ocean, deep subsurface chlorophyll maxima (SCMs) that significantly contribute to primary production (PP) are often observed. These are neither detected by ocean color sensors nor accounted for in the primary production models applied to the Arctic Ocean. Here, we assemble a large database of pan-Arctic observations (i.e., 5206 stations) and develop an empirical model to estimate vertical chlorophyll $a$ (Chl $a$ ) according to (1) the shelf-offshore gradient delimited by the $50 \mathrm{~m}$ isobath, (2) seasonal variability along pre-bloom, post-bloom, and winter periods, and (3) regional differences across ten sub-Arctic and Arctic seas. Our detailed analysis of the dataset shows that, for the pre-bloom and winter periods, as well as for high surface $\mathrm{Chl} a$ concentration (Chl $a_{\text {surf }} ; 0.7-30 \mathrm{mg} \mathrm{m}^{-3}$ ) throughout the open water period, the Chl $a$ maximum is mainly located at or near the surface. Deep SCMs occur chiefly during the post-bloom period when Chl $a_{\text {surf }}$ is low $\left(0-0.5 \mathrm{mg} \mathrm{m}^{-3}\right)$. By applying our empirical model to annual Chl $a_{\text {surf }}$ time series, instead of the conventional method assuming vertically homogenous Chl $a$, we produce novel pan-Arctic PP estimates and associated uncertainties. Our results show that vertical variations in Chl $a$ have a limited impact on annual depth-
\end{abstract}

integrated PP. Small overestimates found when SCMs are shallow (i.e., pre-bloom, post-bloom $>0.7 \mathrm{mg} \mathrm{m}^{-3}$, and the winter period) somehow compensate for the underestimates found when SCMs are deep (i.e., post-bloom $<0.5 \mathrm{mg} \mathrm{m}^{-3}$ ). SCMs are, however, important seasonal features with a substantial impact on depth-integrated PP estimates, especially when surface nitrate is exhausted in the Arctic Ocean and where highly stratified and oligotrophic conditions prevail.

\section{Introduction}

Arctic phytoplankton communities are currently exposed to major environmental change (Wassmann et al., 2011; Tremblay et al., 2012). The current and near-future response of phytoplankton primary production (PP) to these changes is difficult to determine because the impact of environmental variables and their evolution is poorly known in a changing Arctic (Carmack et al., 2006; Wassmann and Reigstad, 2011).

Ocean color (OC) remote sensing provides a powerful medium for monitoring phytoplankton PP at large scales and for studying the response of phytoplankton to global change (e.g., Behrenfeld et al., 2006). A general consensus of satellite-based PP estimates in the Arctic Ocean indicates a significant rise in PP, due mainly to secular increases in both 
the extent and the duration of the open water season (Pabi et al., 2008; Vetrov and Romankevich, 2009; Arrigo and van Dijken, 2011; Bélanger et al., 2013). However, several in situ studies have highlighted the inability of satellites OC sensors to detect subsurface peaks of phytoplankton biomass, the socalled subsurface chlorophyll maxima (SCMs), and stressed that the contribution of SCM to areal PP in the Arctic Ocean is omitted from PP estimates based on OC remote sensing (Hill et al., 2005; Weston et al., 2005; Martin et al., 2010). Moreover, the increase in satellite-derived PP is in disagreement with other in situ, experimental, and modeling studies, showing contrasting responses of phytoplankton production and community structure to environmental forcing ( $\mathrm{Li}$ et al., 2009; Cai et al., 2011; Wassmann and Reigstad, 2011). Arrigo et al. (2011) proposed that the magnitude of the error resulting from the omission of SCM in satellite-based PP estimates varies significantly in space over an annual cycle ( 0.2 to $16 \%$ ). Hill et al. (2013), however, recently suggested a constant PP underestimation of $75 \%$ throughout the summer for the entire Arctic Ocean. At the pan-Arctic scale, these studies reveal that the importance of the SCM in annual PP estimates is still a subject of discussion.

The Arctic Ocean is characterized by a pronounced haline stratification within the surface layer due to the thaw-freeze cycle of sea ice and large freshwater inputs (Carmack and Wassmann, 2006). Present over most of the Arctic Ocean, a polar mixed layer (PML) $40 \mathrm{~m}$ thick sits on the Pacific or Atlantic halocline layer (HL) (Carmack, 2007; Lansard et al., 2012). Shortly after the phytoplankton spring bloom, the PML becomes and remains nitrogen-depleted due to strong vertical stratification, which prevents replenishment during the summer season (Tremblay et al., 2008). As a result, phytoplankton grow below the PML to form a SCM, where sufficient light and nutrients are available. Most of these Arctic SCMs are located well below the pycnocline in close association with the nitracline, which confirms that the vertical position of SCM is mainly driven by a shortage of inorganic nitrogen in the upper euphotic zone (Tremblay et al., 2008; Martin et al., 2010; Ardyna et al., 2011). Unlike the SCMs observed at tropical and temperate latitudes (Cullen, 1982), SCMs in the Arctic Ocean often correspond to maxima of particulate carbon and PP (Weston et al., 2005; Martin et al., 2010). Whether or not the presence of the SCM is ubiquitous in the Arctic Ocean in post-bloom conditions remains to be demonstrated based on more observations. SCMs have recently been described as important sites for predator-prey interactions and may thus play a critical role in trophic coupling (Scott et al., 2010).

The above considerations overlook variability in the vertical chlorophyll $a(\mathrm{Chl} a)$ distribution and the occurrence of SCM in both space and time in the Arctic Ocean. In addition, the importance of the magnitude of the error in depthintegrated PP caused by the omission of the SCM or throughout the whole growing season has not yet been well documented. The first objective of the present study was therefore to thoroughly investigate the spatial and temporal variability in the vertical Chl $a$ distribution in the Arctic Ocean. To reach this goal, 5206 vertical Chl $a$ profiles from various Arctic environments (i.e., fjords, coastal and oceanic regions) as well as different sub-Arctic and Arctic seas were compiled and analyzed. The second objective was to quantify the magnitude of the error in depth-integrated PP due to the presence of SCM throughout the growing season for the entire Arctic Ocean, using a validated depth-integrated PP algorithm. After establishing a pan-Arctic description of the vertical Chl $a$ distribution, the third objective was to develop an empirical model for the estimation of the vertical Chl $a$ profiles based on surface Chl $a$ information for the different seasons and regions of the Arctic Ocean. This study will contribute to improvement of PP estimates based on OC data by providing a powerful and robust tool for estimating the spatiotemporal variability of the vertical $\mathrm{Chl} a$ distribution and understanding SCM dynamics throughout the Arctic Ocean.

\section{Methods}

\subsection{Vertical chlorophyll $a$ database and regional delimitation}

A large dataset of vertical Chl $a$ profiles collected in the Arctic Ocean was assembled (see details in Fig. 1 and Table 2, and see Table 1 for a list of symbols and units). The major dataset used was the ARCSS-PP (Arctic System Science primary production; http://www.nodc.noaa.gov/cgi-bin/ OAS/prd/accession/details/63065), which was recently compiled by Matrai et al. (2013). Matrai et al. (2013) described in details the spatiotemporal heterogeneity of the dataset. It should be noted that intrinsic and potential biases related to the dataset are inevitable and caution is recommended. It consists of a total of 14791 stations visited once over a $50 \mathrm{yr}$ period (1954-2007). For a significant number of stations in this dataset, only surface or shallow $\mathrm{Chl} a$ concentrations were available. Those stations were not considered in the present study. Other datasets included in this study were collected mainly in the Chukchi Sea, Beaufort Sea, Canadian Archipelago, Hudson Bay, and Baffin Bay (Table 2).

A rigorous validation of each vertical $\mathrm{Chl} a$ profile was achieved according to the following three criteria: (1) the uppermost sample of the profile had to be collected between the surface and a depth of $10 \mathrm{~m}$; (2) the lowermost sample of the profile had to be collected at or below the base of the euphotic zone ( $1 \%$ of the surface irradiance), or at least at a depth of $75 \mathrm{~m}$ or $15 \mathrm{~m}$ above the bottom depth $\left(Z_{\mathrm{BOT}}\right)$ for shallower stations; and (3) a minimum of four discrete sampling depths were required. Application of these stringent criteria reduced the initial dataset to 5655 profiles. Furthermore, visual inspection of each individual Chl $a$ profile was performed to discard profiles with a vertical sample distribution inappropriate to describe important features such as 
Table 1. Symbols used in the present study and their unit and definition ( $\varnothing=$ no unit).

\begin{tabular}{|c|c|c|}
\hline Symbol & Unit & Definition \\
\hline$a_{\mathrm{NAP}}(\lambda)$ & $\mathrm{m}^{-1}$ & nonalgal particle absorption coefficient at $\lambda$ \\
\hline$a_{\mathrm{CDOM}}(\lambda)$ & $\mathrm{m}^{-1}$ & colored dissolved organic matter absorption coefficient at $\lambda$ \\
\hline$a_{\varphi}(\lambda)$ & $\mathrm{m}^{-1}$ & phytoplankton absorption coefficient at $\lambda$ \\
\hline$a_{\mathrm{t}}(\lambda)$ & $\mathrm{m}^{-1}$ & total absorption coefficient at $\lambda$ \\
\hline$a_{\mathrm{W}}(\lambda)$ & $\mathrm{m}^{-1}$ & pure water absorption coefficient at $\lambda$ \\
\hline$b_{\mathrm{b}}(\lambda)$ & $\mathrm{m}^{-1}$ & total backscattering coefficient at $\lambda$ \\
\hline$b_{\mathrm{bp}}(\lambda)$ & $m^{-1}$ & backscattering coefficient of particles at $\lambda$ \\
\hline$b_{\mathrm{bw}}(\lambda)$ & $m^{-1}$ & backscattering coefficient of pure seawater at $\lambda$ \\
\hline Chl $a$ & $\mathrm{mg} \mathrm{m}^{-3}$ & chlorophyll $a$ concentration \\
\hline Chl $a_{\text {surf }}$ & $\mathrm{mg} \mathrm{m}^{-3}$ & average chlorophyll $a$ within the surface layer $0-10 \mathrm{~m}$ \\
\hline Chl $a_{Z_{\mathrm{EU}}}$ & $\mathrm{mg} \mathrm{m}^{-2}$ & chlorophyll $a$ integrated over $Z_{\mathrm{EU}}$ \\
\hline$E_{0}(\lambda, 0)$ & $\mu \mathrm{mol}$ photons $\mathrm{m}^{-2} \mathrm{~s}^{-1}$ & spectral scalar irradiance at $\lambda$ beneath the surface \\
\hline$E_{\mathrm{d}}(\lambda, z)$ & $\mu \mathrm{mol}$ photons $\mathrm{m}^{-2} \mathrm{~s}^{-1}$ & total downwelling irradiance at $\lambda$ at $z$ \\
\hline$E_{k}$ PUR & $\mu \mathrm{mol}$ photons $\mathrm{m}^{-2} \mathrm{~s}^{-1}$ & photoacclimation parameter \\
\hline$\gamma$ & $\varnothing$ & spectral dependency of backscattering \\
\hline$K_{\mathrm{d}}(\lambda, z)$ & $m^{-1}$ & diffuse attenuation coefficient of downwelling irradiance at $\lambda$ at $z$ \\
\hline$P_{\max }^{B}$ & $\operatorname{mg~C}(\operatorname{mg~Chl} a)^{-1} \mathrm{~h}^{-1}$ & chlorophyll $a$-specific maximum photosynthetic rate \\
\hline PAR, PUR & $\mu \mathrm{mol}$ photons $\mathrm{m}^{-2} \mathrm{~s}^{-1}$ & photosynthetically available and usable radiation $(400-700 \mathrm{~nm})$ \\
\hline PP & $\mathrm{mg} \mathrm{Cm}^{-2} \mathrm{~d}^{-1}$ & modeled particulate primary production \\
\hline $\mathrm{PP}_{\text {in situ }}$ & $\mathrm{mgCm} \mathrm{m}^{-2} \mathrm{~d}^{-1}$ & in situ particulate primary production measurement \\
\hline & $\varnothing$ & surface salinity within $0-5 \mathrm{~m}$ \\
\hline$z$ & $\mathrm{~m}$ & geometrical depth \\
\hline$\zeta$ & $\varnothing$ & depth normalized with respect to $\zeta=z / Z_{\mathrm{BOT}}$ \\
\hline$Z_{\text {BOT }}$ & $\mathrm{m}$ & bottom depth \\
\hline$Z_{\mathrm{EU}}$ & $\mathrm{m}$ & $\begin{array}{l}\text { depth of the euphotic zone, defined as the depth where the PAR is } \\
\text { reduced to } 1 \% \text { of its surface value }\end{array}$ \\
\hline$Z_{\text {base }}$ & $\mathrm{m}$ & lowest depth of a Chl $a$ measurement of a vertical $\mathrm{Chl} a$ profile \\
\hline$Z_{\mathrm{SCM}}$ & $\mathrm{m}$ & depth of the subsurface chlorophyll maximum \\
\hline
\end{tabular}

the SCM. This second step resulted in a total of 5206 usable profiles.

Because of the difficulty to access the Arctic Ocean in winter, the database mostly covers the sea-ice-free months between April and September (Fig. 2a). However, several campaigns (e.g., CASES, CFL) allow a characterization of the Arctic winter conditions (i.e., polar night and under-ice condition). Baffin Bay, Barents Sea, Beaufort Sea, Bering Sea, Canadian Archipelago, Chukchi Sea, Greenland-Norwegian seas, and the central Arctic Ocean are relatively well covered. The Hudson Bay and the Russian seas are, unfortunately, poorly sampled in both space and time (Figs. 1 and 2b).

\subsection{Approach for modeling the chlorophyll $a$ vertical profiles}

Several studies proposed empirical approaches to statistically describe the variations in the shape of the vertical Chl $a$ profile at low and medium latitudes in the world ocean (Lewis et al., 1983; Platt et al., 1988; Morel and Berthon, 1989; Uitz et al., 2006). In the present study, the vertical Chl $a$ pro- files were parameterized using a modification of the Gaussian equation of Uitz et al. (2006):

$c(z)=C_{\mathrm{b}}-s z+C_{\max } e^{-\left[\left(\frac{z-Z_{\max }}{\Delta z}\right)^{2}\right]}$

where $c(z)$ is the normalized Chl $a$ concentration at depth $z$ (see Eq. 2 ), and $\left(C_{\mathrm{b}}-s z\right)$ is the Chl $a$ background defined by a linear decreasing slope $s$, starting from the normalized surface Chl $a$ concentration $C_{\mathrm{b}}$ over which a Gaussian curve is superimposed. The parameters of the Gaussian curve are the normalized maximum Chl $a$ concentration given by $C_{\max }$, occurring at the depth $Z_{\max }$, and having a thickness controlled by $\Delta z$. For fitting Eq. (1) to measured Chl $a$ vertical profiles (Chl $\left.a(z), \mathrm{mg} \mathrm{m}^{-3}\right), c(z)$ can be derived from

$c(z)=\frac{\operatorname{Chl} a(z)}{\overline{\operatorname{Chl}}_{Z_{\text {base }}}}$,

where $\overline{\mathrm{Chl}}_{Z_{\mathrm{base}}}\left(\mathrm{mg} \mathrm{m}^{-3}\right)$ is the average Chl $a$ concentration of the vertical Chl $a$ profile, obtained by trapezoidal integration using the discrete $\mathrm{Chl} a$ concentration measurements 
Table 2. Information concerning the expeditions and databases where chlorophyll $a(\mathrm{Chl} a)$ and primary production (PP $\left.\mathrm{Pn}_{\text {situ }}\right)$ data were obtained for the present study. Expeditions and databases from the ARCSS-PP database (Matrai et al., 2013) are italicized. Processing

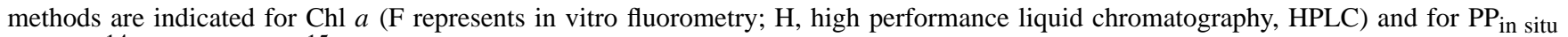
$\left(\mathrm{PC}=\mathrm{DI}^{14} \mathrm{C}\right.$ uptake; $\mathrm{PN}={ }^{15} \mathrm{NO}_{3}$ uptake). * See Matrai et al. (2013) for further details on the methods and quality controls of ARCSS-PP database. The different sub-Arctic and Arctic seas are labeled as follows: 1: Greenland-Norwegian seas, 2: Bering Sea, 3: Chukchi Sea, 4: Barents Sea, 5: Canadian Archipelago, 6: Beaufort Sea, 7: Baffin Bay, 8: central Arctic Ocean, 9: Hudson Bay, 10: Russian seas.

\begin{tabular}{|c|c|c|c|c|c|}
\hline \multirow{2}{*}{$\begin{array}{l}\text { Expedition } \\
\text { or database }\end{array}$} & \multicolumn{2}{|c|}{ No. of stations } & \multirow[t]{2}{*}{ Method } & \multirow{2}{*}{$\begin{array}{l}\text { Sub-Arctic and } \\
\text { Arctic seas }\end{array}$} & \multirow[t]{2}{*}{ Reference/Investigator } \\
\hline & Chl $a$ & $\mathrm{PP}_{\text {in situ }}$ & & & \\
\hline AOS & 19 & & $\mathrm{~F}$ & 3,8 & Gosselin et al. (1997) \\
\hline ArcNut & $1337 / 2662$ & & $*$ & $1,3,4,5,6,7$ & $*$ \\
\hline ArcticNet & 186 & 82 & $\mathrm{~F} \& \mathrm{PC}$ & $5,6,7,9$ & $\begin{array}{l}\text { Tremblay et al. (2009); } \\
\text { Ardyna et al. (2011); } \\
\text { Tremblay et al. (2011); } \\
\text { M. Gosselin (unpubl. data) }\end{array}$ \\
\hline$B A A S 2000$ & $127 / 383$ & & $*$ & $1,4,10$ & $*$ \\
\hline$B P D$ & $20 / 193$ & & $*$ & $3,6,7,8$ & $*$ \\
\hline BioChem & $137 / 921$ & & $*$ & 5,7 & $*$ \\
\hline CABANERA & 12 & 12 & $\mathrm{~F} \& \mathrm{PC}$ & 4,8 & Hodal et al. (2008) \\
\hline CASES & 129 & 23 & F \& PC & 5,6 & $\begin{array}{l}\text { Brugel et al. (2009); } \\
\text { Tremblay et al. (2011) }\end{array}$ \\
\hline CFL & 61 & 7 & $\mathrm{~F} \& \mathrm{PC}$ & $5,6,8$ & $\begin{array}{l}\text { Mundy et al. (2009); } \\
\text { Sallon et al. (2011); } \\
\text { M. Gosselin (unpubl. data) }\end{array}$ \\
\hline ICES & $636 / 2932$ & & $*$ & $1,4,5,8,10$ & $*$ \\
\hline JAMSTEC & 228 & 15 & $\mathrm{~F} \& \mathrm{PC}$ & $3,6,8$ & Nishino et al. (2011a, b) \\
\hline Malina & 42 & 8 & $\mathrm{H} \& \mathrm{PN}$ & 6 & $\begin{array}{l}\text { H. Claustre (unpubl. data); } \\
\text { P. Raimbault (unpubl. data) }\end{array}$ \\
\hline MERICA & 50 & 18 & $\mathrm{~F} \& \mathrm{PC}$ & 5,9 & $\begin{array}{l}\text { Ferland et al. (2011); } \\
\text { Estrada et al. (2012); } \\
\text { Lapoussière et al. (2013) }\end{array}$ \\
\hline NEW & 126 & 10 & $\mathrm{~F} \& \mathrm{PC}$ & 1,8 & Pesant et al. (1996) \\
\hline NSIDC & $175 / 208$ & & $*$ & 2,3 & * \\
\hline$N O D C$ & $1014 / 3090$ & & $*$ & $1,3,4,5,6,7,8,10$ & $*$ \\
\hline NOW & 104 & 56 & $\mathrm{~F} \& \mathrm{PC}$ & 7 & Klein et al. (2002) \\
\hline PANGEA & $551 / 671$ & & $*$ & $1,4,8,10$ & $*$ \\
\hline SBI & $38 / 100$ & 90 & $\mathrm{H} \& \mathrm{PC}$ & $3,6,8$ & Hill et al. (2005) \\
\hline SeaBASS & $150 / 935$ & & $*$ & $1,5,6,7$ & $*$ \\
\hline Rey and Loeng (1985) & $6 / 8$ & & $*$ & 4 & $*$ \\
\hline Vedernikov et al. (1995) & $3 / 32$ & & $*$ & 10 & $*$ \\
\hline Vedernikov et al. (2001) & $6 / 39$ & & $*$ & 10 & $*$ \\
\hline Hill V. database & $14 / 38$ & & $*$ & $3,5,6,8$ & $*$ \\
\hline Matrai P. database & $34 / 43$ & & $*$ & 4,8 & $*$ \\
\hline
\end{tabular}

$\overline{\operatorname{Chl}}_{Z_{\text {base }}}=\left(Z_{\text {base }}\right)^{-1} \int_{0}^{Z_{\text {base }}} \operatorname{Chl} a \mathrm{~d} z$,

where $Z_{\text {base }}$ is the lowest depth of the vertical Chl $a$ profile. The uppermost discrete sampling, located in the first $10 \mathrm{~m}$, is extended until the surface to perform the trapezoidal integration on the entire profile.

Morel and Berthon (1989) and Uitz et al. (2006) fitted their equivalent of Eq. (1) to measured vertical Chl $a$ profiles binned as a function of surface $\mathrm{Chl} a\left(\mathrm{Chl} a_{\text {surf }}, \mathrm{mg} \mathrm{m}^{-3}\right)$, and derived sets of Eq. (1) parameters for each $\mathrm{Chl} a_{\text {surf }}$ bin. In this procedure, the binning step is necessary because individual measured Chl $a$ profiles are often too poorly vertically resolved. Morel and Berthon (1989) and Uitz et al. (2006) pooled all retrieved-parameter vs. Chl $a_{\text {surf }}$ couples, and derived empirical relationships between retrieved parameters of Eq. 1 and $\mathrm{Chl} a_{\text {surf. The resulting empirical model yields }}$ vertical Chl $a$ profiles as a function of Chl $a_{\text {surf. The mod- }}$ els developed by Morel and Berthon (1989) and Uitz et al. (2006) were applied at low and moderate latitudes, at large and global scales, and when the euphotic zone was deeper than the mixed layer based on climatological data 


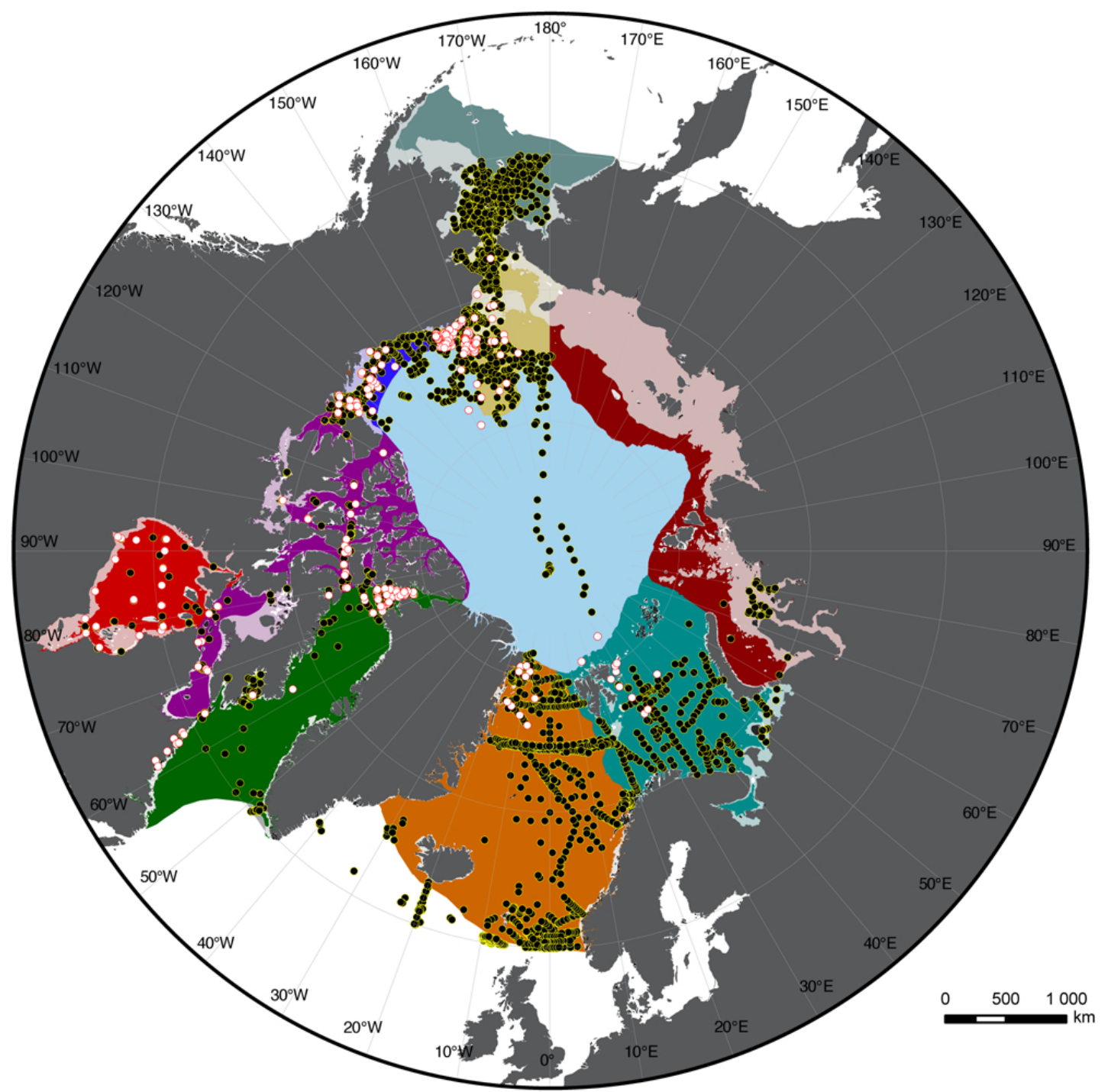

\section{Arctic and Sub-Arctic seas}

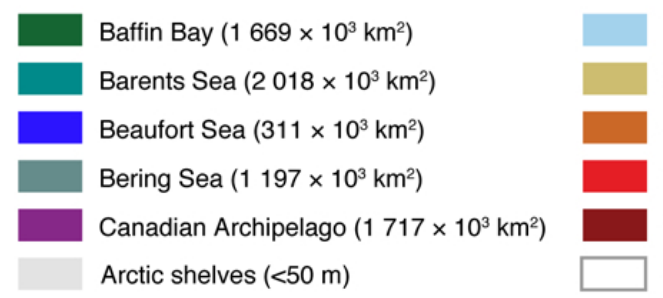

Central Arctic Ocean $\left(4137 \times 10^{3} \mathrm{~km}^{2}\right)$

Chukchi Sea $\left(791 \times 10^{3} \mathrm{~km}^{2}\right)$

Greenland-Norwegian seas $\left(3212 \times 10^{3} \mathrm{~km}^{2}\right)$

Hudson Bay $\left(953 \times 10^{3} \mathrm{~km}^{2}\right)$

Russian seas $\left(2516 \times 10^{3} \mathrm{~km}^{2}\right)$

Others seas

Fig. 1. Locations of the 5206 sampling stations for $(\bullet)$ chlorophyll $a$ and (O) chlorophyll $a$ and primary production in sub-Arctic and Arctic seas (map adapted from Spalding et al. (2007) and the WWF agency) and shelves $(\leq 50 \mathrm{~m})$. The area of each sub-Arctic and Arctic sea is also indicated.

(e.g., Antoine and Morel, 1996; Uitz et al., 2006). We were not successful in applying this simple approach to the Arctic Ocean, most probably because Arctic phytoplankton communities are exposed to very pronounced seasonality associated with light conditions, sea-ice cover, and nutrient avail- ability (Harrison and Cota, 1991; Grebmeier et al., 1995), and because the mixed layer depth and vertical stratification are controlled by salinity in several Arctic regions rather than temperature (Carmack, 2007). 

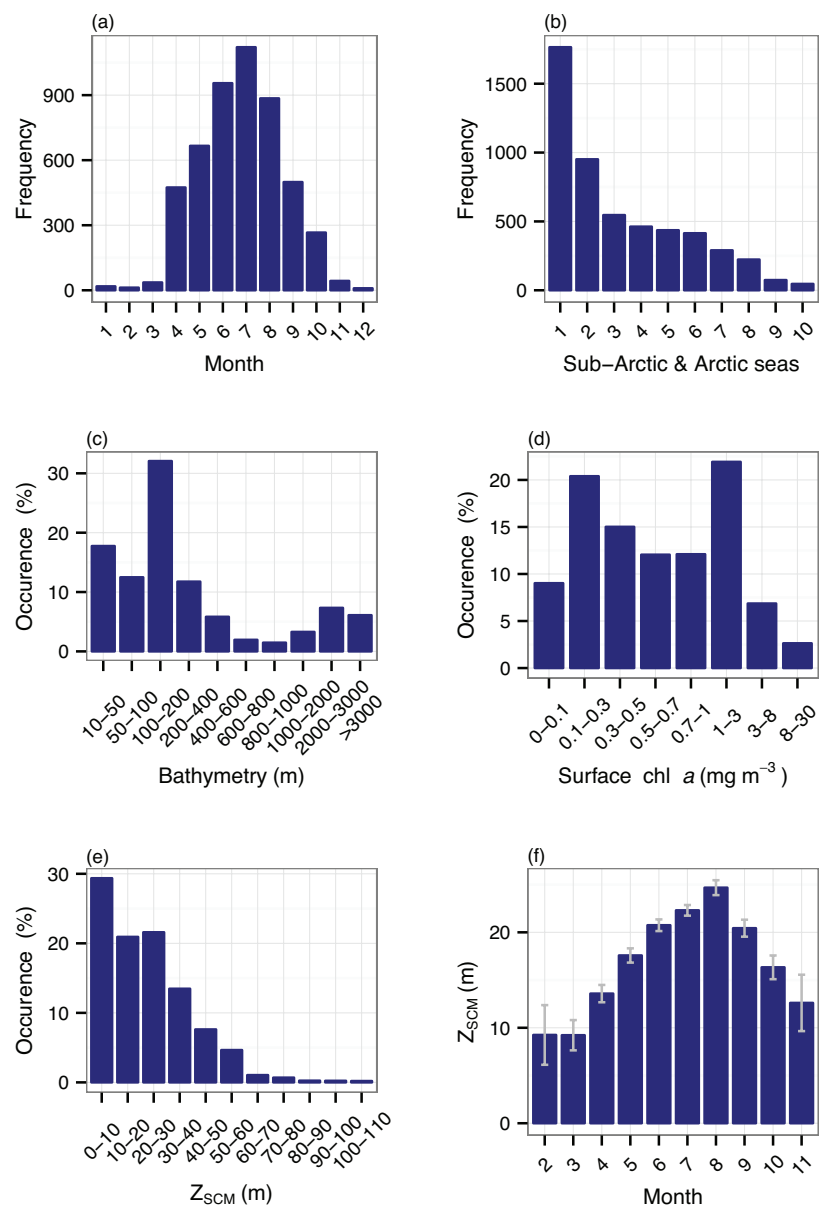

Fig. 2. Frequency distributions of number of sampled stations as a function of (a) month of the year, and (b) sub-Arctic and Arctic seas labeled in the Table 2; occurrence of sampled stations as a function of (c) bathymetry, (d) surface chlorophyll $a$ (Chl $a_{\text {surf }}$ ) concentration, and (e) $Z_{\mathrm{SCM}}$ depth; (f) monthly variation of average $Z_{\mathrm{SCM}}$. In (f), errors bars represent standard error.

Here, we first partitioned our dataset according to bathymetry, season, and region. In our procedure, each vertical Chl $a$ profile was linearly interpolated at $1 \mathrm{~m}$ resolution, normalized (see Eqs. 2 and 3), grouped by bins, and averaged within each bin. The parameters of Eq. 1 were retrieved for the averaged Chl $a$ profiles. The model uses a set of parameters as a function of location, time, depth, and Chl $a_{\text {surf }}$.

\subsection{Description of the empirical model}

On the basis of a preliminary analysis to break down the dataset in a synthetic manner (see Fig. 3), the stations were partitioned according to the following three criteria: i Shallow $(\leq 50 \mathrm{~m})$ and deep $(>50 \mathrm{~m})$ stations were considered separately. The former category represents $17.6 \%$ of the total number of stations (Fig. 2c) and $18.3 \%$ of the total area of Arctic and sub-Arctic seas (Fig. 1). This was a crucial step to avoid multiple biases on the characterization of the vertical $\mathrm{Chl} a$ profiles and the assessment of the occurrence of SCM. A second normalization was needed for the shallow stations, which consists in division of the geometrical depth, $z(\mathrm{~m})$, by the bottom depth $Z_{\mathrm{BOT}}(\mathrm{m})$ :

$\zeta=\frac{z}{Z_{\mathrm{BOT}}}$.

ii The dataset was partitioned into the following three separate time periods: pre-bloom (February-April), postbloom (May-September) and winter period (OctoberDecember). For the development of the empirical model, however, the partitioning of the time periods is based on the conceptual scheme illustrated in Fig. 4, which depicts the annual cycle of the Chl $a_{\text {surf }}$ concentration throughout the growing season. The temporal threshold between the pre-bloom and the post-bloom periods was defined as the annual highest $\operatorname{Chl} a_{\text {surf value }}$ when the spring bloom reaches its paroxysm (Fig. 4). Hence, the empirical model does not contain a specific period of spring bloom. When the sea-ice-free period is long enough, a fall bloom is expected, owing to nutrient replenishments at the surface layer by forcing events (i.e., convective mixing and upwelling) during the late season. The temporal threshold between the post-bloom and winter period was defined as the time when daylight becomes less than nine hours. This threshold corresponds to the approximate length of photoperiod below which the SCM is no more observed within any bin (data not shown).

iii Finally, a regionalization of the dataset was needed for the post-bloom period when the occurrence of SCM is significantly deeper compared to the two other periods (Fig. 2f). Using a revised regional partition proposed initially by Spalding et al. (2007) and the WWF (World Wildlife Fund) agency, 10 sub-Arctic and Arctic seas were defined to assess regional differences in the depth, shape, and magnitude of SCM (Fig. 1).

The empirical model of the vertical $\mathrm{Chl} a$ profiles was thus developed for sub-Arctic and Arctic seas ( $\mathrm{C}$ categories $>50 \mathrm{~m}$; see Table 3) and Arctic shelves (CC categories $\leq 50 \mathrm{~m}$; see Table 5), and for three distinct periods (i.e., prebloom, post-bloom, and winter period; Fig. 4). It is based on eight $\mathrm{Chl} a_{\text {surf }}$ bins (C1 and CC1: $0-0.1 \mathrm{mg} \mathrm{m}^{-3}, \mathrm{C} 2$ and CC2: $0.1-0.3 \mathrm{mg} \mathrm{m}^{-3}, \mathrm{C} 3$ and CC3: $0.3-0.5 \mathrm{mg} \mathrm{m}^{-3}, \mathrm{C} 4$ and CC4: $0.5-0.7 \mathrm{mg} \mathrm{m}^{-3}, \mathrm{C} 5$ and CC5: $0.7-1 \mathrm{mg} \mathrm{m}^{-3}$, C6 and CC6: $1-3 \mathrm{mg} \mathrm{m}^{-3}, \mathrm{C} 7$ and CC7: $3-8 \mathrm{mg} \mathrm{m}^{-3}, \mathrm{C} 8$ and CC8: $8-30 \mathrm{mg} \mathrm{m}^{-3}$; see Fig. 2d). 


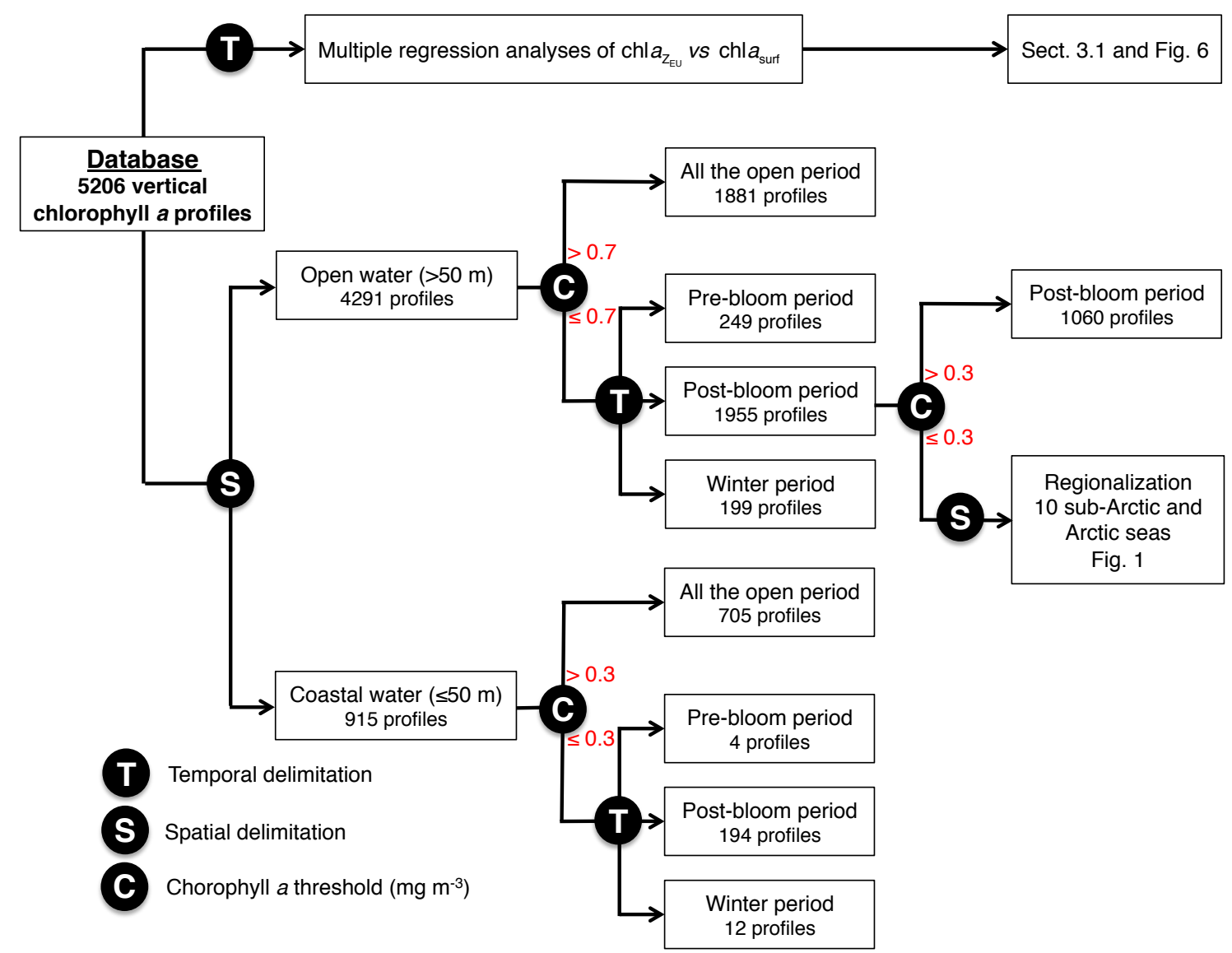

Fig. 3. A flowchart showing the partition and the use of the database (after quality control) for establishing the empirical model.

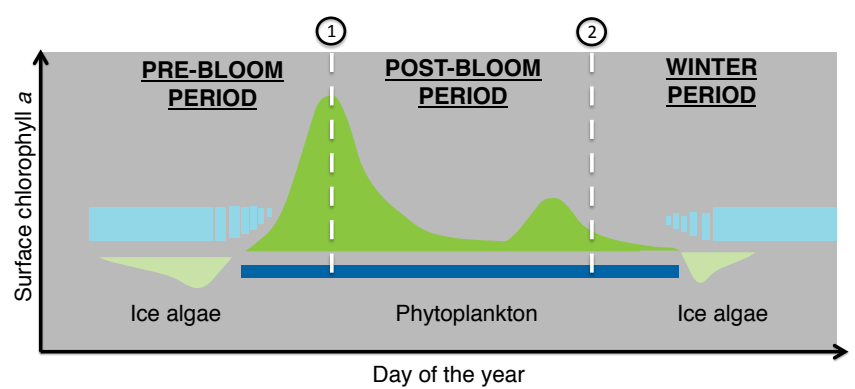

Fig. 4. Conceptual overview of an annual time series of surface $\mathrm{Chl} a$ (Chl $\left.a_{\text {surf }}\right)$ concentration throughout the growing season. The first and second temporal delimitation are defined by the highest value of surface Chl $a$ (i.e., the paroxysm of the spring bloom) and a threshold of $9 \mathrm{~h}$ of daylight, respectively. Modified from Wassmann and Reigstad (2011).

The Chl $a_{\text {surf }}$ bins for the different clusters and the number of profiles per cluster are shown in Fig. 2d. Profiles were then averaged for each cluster. Equation (1) was fitted to each average profile and the parameters $\left(C_{\mathrm{b}}, s, C_{\max }, Z_{\max }, \Delta z\right)$ estimated. The search of the optimal parameters were performed using a nonlinear least-squares function, starting with an en- semble of initial guesses on an open interval between the approximated lower and upper bounds of parameters. The nonlinear least-squares function is not sensitive to the initial guesses, when convergence is achieved (Bates and Watts, 1988).

\subsection{Primary production algorithm}

A spectrally resolved model for estimating depth-integrated PP was adapted from Bélanger et al. (2013) to account for non-homogeneous Chl $a$ profiles and for our specific input data. The depth-integrated PP depends primarily on light availability, biomass as expressed by $\mathrm{Chl} a$ concentration, and the ability of phytoplankton to harvest the available light (photosynthetically usable radiation, PUR) and can be expressed as follows:

$\mathrm{PP}=P_{\max }^{B} \int_{t=0}^{24} \int_{z=0}^{\mathrm{h} 100 \mathrm{~m} \text { or }} \operatorname{ZBOT}_{\text {BOT }} \operatorname{Chl}(z)\left[1-e^{\frac{-\mathrm{PUR}(z, t)}{E_{k} \operatorname{PUR}(z)}}\right] \mathrm{d} z \mathrm{~d} t$,

where the modeled daily rate of PP $\left(\mathrm{mgC} \mathrm{m}^{-2} \mathrm{~d}^{-1}\right)$ is a function of $\operatorname{PUR}(z, t)\left(\mu \mathrm{mol}\right.$ photons $\left.\mathrm{m}^{-2} \mathrm{~s}^{-1}\right)$, Chl $a$ concentration $\left(\mathrm{mg} \mathrm{m}^{-3}\right)$, the maximum rate of carbon fixation 
$\left(P_{\max }^{B}, \operatorname{mgC}\left(\operatorname{mgChl} a^{-1}\right) \mathrm{h}^{-1}\right)$ and the PUR value at which photosynthesis approaches saturation $\left(E_{k}\right.$ PUR $(z)$, $\mu$ mol photons $\mathrm{m}^{-2} \mathrm{~s}^{-1}$ ).

PUR is a function of the spectrally resolved irradiance $\left(E_{\mathrm{d}}(\lambda, z), \mu\right.$ mol photons $\left.\mathrm{m}^{-2} \mathrm{~s}^{-1}\right)$ and the spectral phytoplankton absorption coefficient $\left(a_{\varphi}(\lambda, z), \mathrm{m}^{-1}\right)$ at that depth (Morel, 1978):

$\operatorname{PUR}(z, t)=\int_{400}^{700 \mathrm{~nm}} E_{\mathrm{d}}(\lambda, z, t)\left(\frac{a_{\varphi}(\lambda, z)}{a_{\varphi}(443, z)}\right) \mathrm{d} \lambda$.

Based on the study of Huot et al. (2013) carried out in the Arctic Ocean, we adopted a constant value of $1.7 \mathrm{mg} \mathrm{C}(\mathrm{mg}$ $\left.\mathrm{Chl} a^{-1}\right) \mathrm{h}^{-1}$ for $P_{\max }^{B}$. Variations of the parameter $E_{k}$ PUR $(z)$ were expressed as a function of the mean daily $\operatorname{PUR}(z)$ value ( $\overline{\mathrm{PUR}}(z), \mu \mathrm{mol}$ photons $\mathrm{m}^{-2} \mathrm{~s}^{-1}$ ) according to the equation

$E_{k \operatorname{PUR}}(z)=\frac{E_{k \mathrm{PUR} \max }}{1+2.2 e^{-[0.336 \overline{\mathrm{PUR}}(z)]}}$,

where $E_{k \text { PUR max }}$ is the maximum $E_{k}$ PUR (i.e., $25.7 \mu$ mol photons $\mathrm{m}^{-2} \mathrm{~s}^{-1}$ ). Equation (7) accounts for photoacclimation such that $E_{k}$ PUR $(z)=\overline{\mathrm{PUR}}(z)$ throughout the euphotic zone and asymptotically approaches $E_{k}$ PURmax toward the surface and $E_{k \text { PUR min }}\left(=8.0 \mu \mathrm{mol}\right.$ photons $\left.\mathrm{m}^{-2} \mathrm{~s}^{-1}\right)$ at the base of the euphotic zone (Huot et al., 2013).

Spectral incident irradiance $\left(E_{0}(\lambda, 0)\right.$, $\mu$ mol photons $\mathrm{m}^{-2} \mathrm{~s}^{-1}$ ), just beneath the surface and for a given location, was extracted from look-up tables (LUT) computed using the atmosphere radiative transfer model of Ricchiazzi et al. (1998). Input parameters for the LUT include the day of the year, time of day, latitude, longitude, cloud fraction, cloud optical thickness, and ozone content (Bélanger et al., 2013). For the latter three variables, we used a daily climatology of satellite data collected between 1984 and 2007 and freely available from the ISCCP (International Satellite Cloud Climatology Project; http://isccp.giss.nasa.gov/) (Zhang et al., 2004). The scalar irradiance $E_{0}(\lambda, 0)$ was computed at $5 \mathrm{~nm}$ intervals as the sum of values obtained for clear and cloudy sky conditions, weighted by the cloud fraction provided by the climatology.

The spectrally resolved irradiance at depth was obtained by applying an exponential decrease of the downwelling irradiance at the surface with a slope of $K_{\mathrm{d}}(\lambda, z)\left(\mathrm{m}^{-1}\right)$, the diffuse attenuation coefficient. The coefficient $K_{\mathrm{d}}(\lambda, z)$ was computed using the total absorption $\left(a_{\mathrm{t}}(\lambda, z), \mathrm{m}^{-1}\right)$ and total backscattering $\left(b_{\mathrm{b}}(\lambda, z), \mathrm{m}^{-1}\right)$ coefficients according to Lee et al. (2005).

$$
K_{\mathrm{d}}(\lambda, z)=m_{0} a_{\mathrm{t}}(\lambda, z)+m_{1}\left(1-m_{2} e^{-m_{3} a_{\mathrm{t}}(\lambda, z)}\right) b_{\mathrm{b}}(\lambda, z),
$$

where $m_{0} \approx 1+0.005 \theta_{\mathrm{a}}$ and $\theta_{a}$ is the solar zenith angle in air. The values for the model constants $\left(m_{1}, m_{2}, m_{3}\right)$ are 4.18 , 0.52 , and 10.8, respectively (Lee et al., 2005).
The total absorption coefficient $a_{t}(\lambda, z)$ was computed as the sum of $a_{\varphi}(\lambda, z)$, non-algal particles $\left(a_{\mathrm{NAP}}(\lambda, z), \mathrm{m}^{-1}\right)$, colored dissolved organic matter $\left(a_{\mathrm{CDOM}}(\lambda, z), \mathrm{m}^{-1}\right)$ and pure water $\left(a_{\mathrm{w}}(\lambda, z), \mathrm{m}^{-1}\right)$. Empirical relationships between non-water absorption components and $\mathrm{Chl} a$ concentrations derived for the Chukchi and Beaufort seas by Matsuoka et al. (2011) were used to determine $a_{\varphi}(\lambda, z)$ and $a_{\mathrm{NAP}}(\lambda, z)$ at $440 \mathrm{~nm}$ :

$a_{\varphi}(440, z)=0.0298[\mathrm{Chl} a(z)]^{0.652}\left(\operatorname{adjusted} r^{2}=0.71\right) ;$

$$
a_{\mathrm{NAP}}(440, z)=0.0131[\mathrm{Chl} a(z)]^{0.528}\left(\text { adjusted } r^{2}=0.47\right)(
$$

The absorption coefficient of CDOM at $440 \mathrm{~nm}$ was estimated using the significant linear relationship between CDOM absorption and surface salinity (sal) observed along a coastal to offshore gradient in the southeastern Beaufort Sea (Bélanger et al., 2006; Matsuoka et al., 2012):

$a_{\mathrm{CDOM}}(440, z)=0.937-0.00338$ [sal] $\left(\right.$ adjusted $\left.r^{2}=0.96\right)$;

for sal range of $0-28 \mathrm{PSU}$

$a_{\mathrm{CDOM}}(440, z)=0.03$; for sal $>28$ PSU.

The spectral values of $a_{\varphi}(\lambda, z)$ according to the statistical relationship between $a_{\varphi}(\lambda, z)$ and $a_{\varphi}(440)$ documented by Matsuoka et al. (2011) in the Chukchi and Beaufort seas can be expressed as

$a_{\varphi}(\lambda, z)=\alpha(\lambda)\left[a_{\varphi}(440, z)\right]^{\beta(\lambda)}$,

where $\alpha(\lambda)$ and $\beta(\lambda)$ are the regression coefficients derived by Matsuoka et al. (2011). Spectra of $a_{\mathrm{NAP}}(\lambda, z)$ and $a_{\mathrm{CDOM}}(\lambda, z)$ can then be expressed as exponential functions as follows (e.g., Bricaud et al., 1981; Babin et al., 2003):

$a_{i}(\lambda)=a_{i}\left(\lambda_{\mathrm{r}}\right) e^{\left(-S_{i}\left(\lambda-\lambda_{\mathrm{r}}\right)\right)}$,

where $i$ denotes either NAP or CDOM, $\lambda_{\mathrm{r}}$ is the reference wavelength (i.e., $440 \mathrm{~nm}$ ), and $S_{\mathrm{NAP}}$ and $S_{\mathrm{CDOM}}$ are the spectral slopes for NAP and CDOM absorptions. Values of $0.0104 \mathrm{~nm}^{-1}$ for $S_{\mathrm{NAP}}$ and $0.018 \mathrm{~nm}^{-1}$ for $S_{\mathrm{CDOM}}$ were derived from Matsuoka et al. (2011). Water absorption $a_{\mathrm{w}}(\lambda)$ was inferred from Pope and Fry (1997).

Using a reference wavelength $\lambda_{0}$ (i.e., $555 \mathrm{~nm}$ ), the total backscattering coefficient was estimated using the following expression:

$b_{\mathrm{b}}(\lambda, z)=\left[b_{\mathrm{bw}}\left(\lambda_{0}\right)+b_{\mathrm{bp}}\left(\lambda_{0}, z\right)\right]\left(\frac{\lambda_{0}}{\lambda}\right)^{\gamma}$,

where $b_{\mathrm{bw}}\left(\lambda_{0}\right)\left(\mathrm{m}^{-1}\right)$ is the backscattering coefficient of pure seawater at $\lambda_{0}$ and $\gamma$ a parameter describing the spectral dependency of backscattering (Reynolds et al., 2001):

$\gamma=-2.348 \log _{10}\left(b_{\mathrm{b}}(555)\right)-4.353$. 
The backscattering coefficient of particles at $555 \mathrm{~nm}$ $\left(b_{\mathrm{b}}(555, \lambda), \mathrm{m}^{-1}\right)$ was derived using the following empirical relationship from Wang et al. (2005):

$b_{\mathrm{bp}}(555, z)=0.004[\mathrm{Chl} a(z)]^{0.357}$.

In order to examine the role of parameterizations of the absorption coefficients to estimate $Z_{\mathrm{EU}}$, four other parameterizations in addition to the one selected (see above) were tested in diverse regions and seasons in the Arctic Ocean. The four additional parameterizations are

(2) $a_{\mathrm{NAP}}, a_{\mathrm{CDOM}}, a_{\varphi}$ : empirical relationships using Chl $a$ concentration (Matsuoka et al., 2011); semi analytical method for estimating $K_{\mathrm{d}}$ (Lee et al., 2005).

(3) $a_{\mathrm{NAP}}, a_{\varphi}$ : empirical relationships using $\mathrm{Chl} a$ concentration (Matsuoka et al., 2011); $a_{\mathrm{CDOM}}$ empirical relationships using the surface salinity (Granskog et al., 2007); semi-analytical method for estimating $K_{\mathrm{d}}$ (Lee et al., 2005).

(4) $a_{\mathrm{NAP}}, a_{\mathrm{CDOM}}, a_{\varphi}$ : empirical relationships using Chl $a$ concentration (Wang et al., 2005); semi-analytical method for estimating $K_{\mathrm{d}}$ (Lee et al., 2005).

(5) Empirical relationship between $K_{\mathrm{d}}$ and Chl $a$ (Morel and Maritorena, 2001).

The validation of the PP algorithm and the results of parameterizations of the absorption coefficients to estimate $Z_{\mathrm{EU}}$ are presented in Appendix A and Table A1.

Two annual depth-integrated PP estimates were then determined for the entire Arctic Ocean with respect to a high (i.e., 1998) and a low (i.e., 2007) annual sea-ice cover (Table 6). The sea-ice climatologies were estimated from the F13 special sensor microwave imager (SSMI) and were obtained from the National Snow and Ice Data Center (NSIDC). Open water area was defined as being sea-ice-free wherever the sea-ice concentration is less than approximately $10 \%$, as arbitrarily defined by previous studies (Arrigo et al., 2008, 2011; Pabi et al., 2008; Perrette et al., 2011). Three classes of bathymetry were then defined for the Arctic shelves (i.e., $0-10 \mathrm{~m}, 10-25 \mathrm{~m}$, and $25-50 \mathrm{~m}$ ) to take into account the impact of $Z_{\mathrm{BOT}}$ and simulate correctly annual depth-integrated PP in Arctic shelves. The bathymetry and area of the Arctic shelves $(<50 \mathrm{~m})$ were derived from the General Bathymetric Chart of the Oceans (GEBCO_08 Grid, http://www.gebco.net/; Fig. 1).

\section{Results and discussion}

\subsection{Empirical model of the vertical Chl $a$ profile}

\subsubsection{Sub-Arctic and Arctic seas $(>50 \mathrm{~m})$}

For the 4 highest Chl $a_{\text {surf }}$ bins (i.e., C5-C8; Fig. 5), Chl $a$ was systematically maximum in the surface layer (i.e., no clear SCM) regardless of the period (Fig. 5). The decrease in Chl $a$ with depth was steeper at high surface concentrations. As shown in Fig. 6, a strong correlation was found between Chl $a_{\text {surf }}$ and depth-integrated Chl $a$ stocks in the euphotic zone (Chl $\left.a_{Z_{\mathrm{EU}}}\right)$ when $\mathrm{Chl} a_{\text {surf }}>0.7 \mathrm{mg} \mathrm{m}^{-3}$ $\left(\mathrm{Chl} a_{\mathrm{ZEU}}=34.67\left[\mathrm{Chl} a_{\mathrm{surf}}\right]^{0.384}\right.$; adjusted $\left.r^{2}=0.82\right)$. For the four lowest Chl $a_{\text {surf }}$ bins (i.e., C1-C4; Fig. 5), strong differences in the average shape of the vertical Chl $a$ profile were observed between the different periods. A robust correlation between Chl $a_{\text {surf }}$ and Chl $a_{Z_{\mathrm{EU}}}$ also characterized the pre-bloom $\left(\mathrm{Chl} a_{Z_{\mathrm{EU}}}=37.98\left[\mathrm{Chl} a_{\mathrm{surf}}\right]^{0.687}\right.$; adjusted $\left.r^{2}=0.79\right)$ and winter $\left(\mathrm{Chl} a_{\mathrm{ZEU}}=32.57\left[\mathrm{Chl} a_{\mathrm{surf}}\right]^{0.618}\right.$; adjusted $r^{2}=0.58$ ) periods (Fig. 6), when maximum Chl $a$ values occurred at the surface for the four bins (C1-C4, Fig. 5). These empirical relationships at low (i.e., $\leq 0.7 \mathrm{mg} \mathrm{m}^{-3}$; prebloom and winter periods) and high (i.e., $>0.7 \mathrm{mg} \mathrm{m}^{-3}$; all the open period) Chl $a$ concentrations are relatively similar, which could be explained by the same pattern in vertical Chl $a$ distribution (Fig. 5). Interestingly, these latter empirical relationships show good agreement with those found in tropical and temperate oceans over the entire range of observed Chl $a_{\text {surf }}$ (Morel and Berthon, 1989; Uitz et al., 2006; Frolov et al., 2012).

Low light availability, which is implicitly linked to the sea-ice cover, might be responsible for limiting phytoplankton growth and maintaining low Chl $a$ level in the surface layer during pre-bloom and winter periods. The onset of the spring bloom and accumulation of high Chl $a$ concentration in the surface layer are then considered possible only when phytoplankton receive enough light for positive growth. The compensation irradiance, which is defined as the irradiance at which gross community primary production balances respiratory carbon losses for the entire community was estimated at ca. 1.3-1.9 mol photons $\mathrm{m}^{-2} \mathrm{~d}^{-1}$ for Arctic diatoms (Tremblay et al., 2006).

The post-bloom period differs significantly from the other periods, with no clear correlation between Chl $a_{\text {surf }}$ and Chl $a_{Z_{\mathrm{EU}}}$ (adjusted $r^{2}=0.07$, Fig. 6). SCMs are systematically found at a depth ranging from 18 to $48 \mathrm{~m}$ and their relative magnitude increases with decreasing Chl $a_{\text {surf }}$ (Fig. 5). However, large standard deviations were observed for bins $\mathrm{C} 1$ and $\mathrm{C} 2$, which reflects significant variability in the shape of the vertical Chl $a$ profile when Chl $a_{\text {surf }}$ is low. We regionalized the $\mathrm{C} 1$ and $\mathrm{C} 2$ bins of the database in order to detect possible spatial structure in terms of depth, shape, and magnitude of the SCM (Fig. 7 and Table 4). When regions were defined as in Fig. 1, strong SCMs in the Bering, Chukchi, 


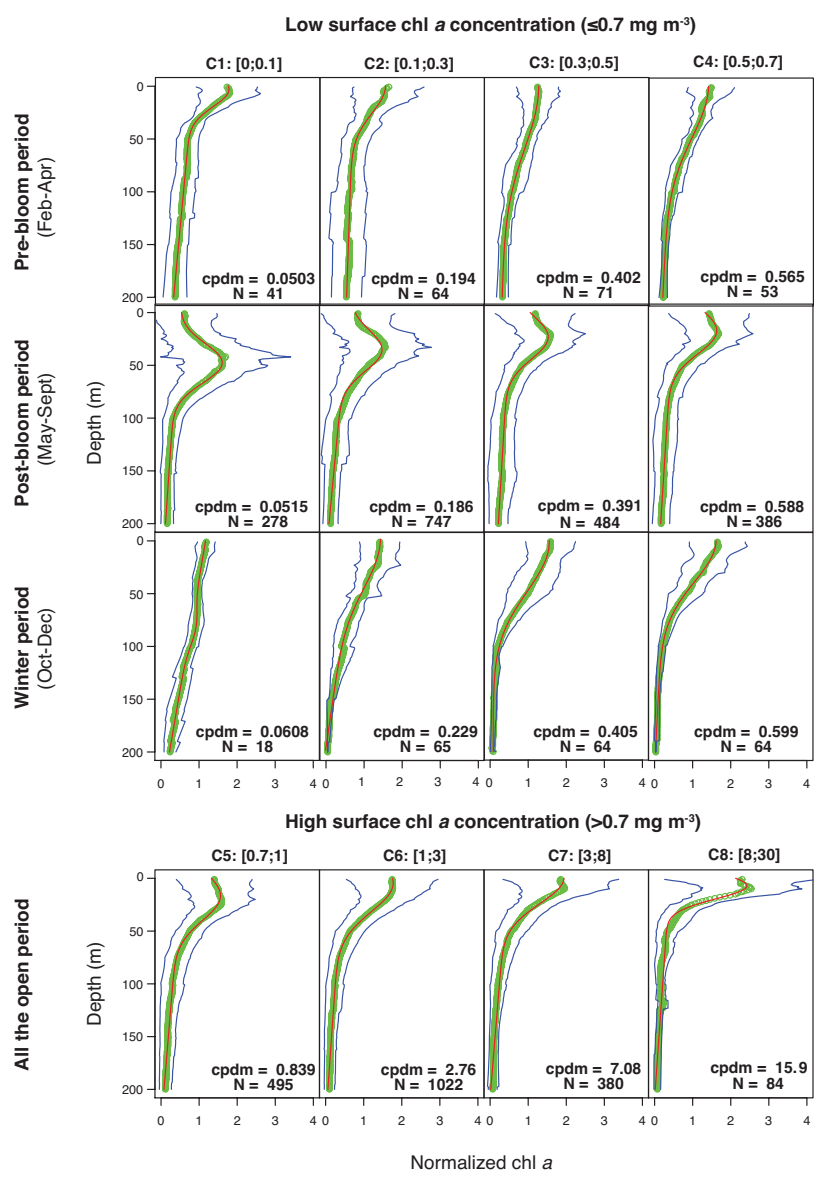

Fig. 5. Average dimensionless chlorophyll $a(\mathrm{Chl} a)$ profiles (green lines) obtained for each category $(\mathrm{C} 1-\mathrm{C} 8)$ during pre-bloom, postbloom, and winter periods as well as over the open water period (i.e., when surface $\mathrm{Chl} a>0.7 \mathrm{mg} \mathrm{m}^{-3}$ ) at deep (>50 m) Arctic stations. Red and blue lines represent the parameterized vertical Chl $a$ profiles and standard deviation, respectively. $\mathrm{N}$ and cpdm represent the number of stations and the averaged $\mathrm{Chl} a_{\text {surf }}$ value, respectively.

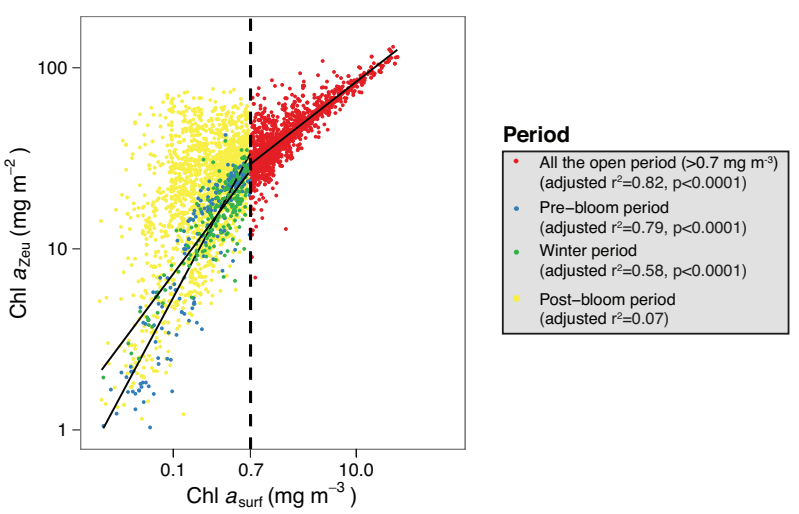

Fig. 6. Integrated chlorophyll $a$ concentration over the euphotic zone (Chl $a_{Z_{\mathrm{EU}}}$; based on the empirical relationships of Morel and Maritorena, 2001) plotted as a function of the surface Chl $a$ concentration (Chl $a_{\text {surf }}$ ) for the three distinct time periods (i.e., pre-bloom, post-bloom, winter, and the open water period $>0.7 \mathrm{mg} \mathrm{m}^{-3}$ ).
Table 3. Estimated values of the five parameters of Equation 1, obtained for the average dimensionless vertical profiles of chlorophyll $a(\mathrm{C} 1-\mathrm{C} 8)$ during different time periods (i.e., pre-bloom, postbloom, winter and entire period of open water $>0.7 \mathrm{mg} \mathrm{m}^{-3}$ ) at deep ( $>50 \mathrm{~m}$ ) Arctic stations.

\begin{tabular}{lccccc}
\hline $\begin{array}{l}\text { Bin } \\
\left.\text { (mg Chl } a \mathrm{~m}^{-3}\right)\end{array}$ & $C_{\mathrm{b}}$ & $s$ & $C_{\max }$ & $Z_{\max }$ & $\Delta z$ \\
\hline \multicolumn{7}{l}{ Pre-bloom (February-April) } & & & & \\
\hline C1 (0-0.1) & 0.8356 & 0.0026 & 0.9450 & 3.83 & 22.21 \\
C2 (0.1-0.3) & 0.7272 & 0.0009 & 0.8371 & 0.00 & 36.20 \\
C3 (0.3-0.5) & 0.4542 & 0.0007 & 0.8127 & 1.91 & 80.52 \\
C4 (0.5-0.7) & 0.4751 & 0.0013 & 0.9337 & 0.00 & 68.35 \\
\hline Post-bloom (May-September) & & & \\
\hline C1 (0-0.1) & 0.4908 & 0.0019 & 1.2039 & 48.07 & 26.43 \\
C2 (0.1-0.3) & 0.6087 & 0.0026 & 0.9656 & 36.05 & 27.27 \\
C3 (0.3-0.5) & 0.5461 & 0.0016 & 1.0198 & 23.81 & 28.47 \\
C4 (0.5-0.7) & 0.5093 & 0.0017 & 1.1552 & 17.77 & 30.12 \\
\hline Winter period (October-December) & & & \\
\hline C1 (0-0.1) & 1.1696 & 0.0045 & 0.1130 & 83.42 & 24.99 \\
C2 (0.1-0.3) & 0.6519 & 0.0030 & 0.7873 & 2.37 & 63.03 \\
C3 (0.3-0.5) & 0.0939 & 0.0001 & 1.4592 & 1.34 & 66.32 \\
C4 (0.5-0.7) & 0.3126 & 0.0013 & 1.3075 & 0.00 & 54.03 \\
\hline Entire period of open water $\left(>0.7 \mathrm{mg}\right.$ Chl $\left.a \mathrm{~m}^{-3}\right)$ & & \\
\hline C5 (0.7-1) & 0.5449 & 0.0023 & 1.1564 & 15.68 & 31.69 \\
C6 (1-3) & 0.4611 & 0.0020 & 1.4783 & 4.81 & 35.92 \\
C7 (3-8) & 0.4870 & 0.0024 & 1.7256 & 0.00 & 31.76 \\
C8 (8-30) & 0.3987 & 0.0019 & 2.1463 & 6.64 & 18.45 \\
\hline
\end{tabular}

Beaufort, and Barents seas as well as in Hudson Bay occurred at the average depth of $42,36,48,51$, and $46 \mathrm{~m}$, respectively (Fig. 7). In Baffin Bay, the Canadian Archipelago, and the central Arctic Ocean, less pronounced SCMs were found at the average depth of 44,38 , and $36 \mathrm{~m}$, respectively. The Russian seas, despite the few data available, seem to be equally characterized by a SCM, at $49 \mathrm{~m}$ on average.

The SCMs have been already described as common features in ice-free Arctic waters during late summer and early fall (Hill et al., 2005; Tremblay et al., 2008; Martin et al., 2010; McLaughlin and Carmack, 2010). With the exhaustion of nitrate in the surface layer, SCMs usually form at the depth of the nitracline, where phytoplankton growth depends on light conditions in combination with nutrient availability (Rysgaard et al., 1999; Martin et al., 2010; Ardyna et al., 2011). These conditions, resulting from a high vertical stability of the upper water column, allow phytoplankton in the lower euphotic zone to exploit the upward nutrient flux for a longer period or to deepen the nitracline until the compensation depth for metabolic balance is attained (Weston et al., 2005; Tremblay et al., 2008; Martin et al., 2010).

Surprisingly, our results show differences in the vertical Chl $a$ distribution with no occurrence of SCM or SCM 


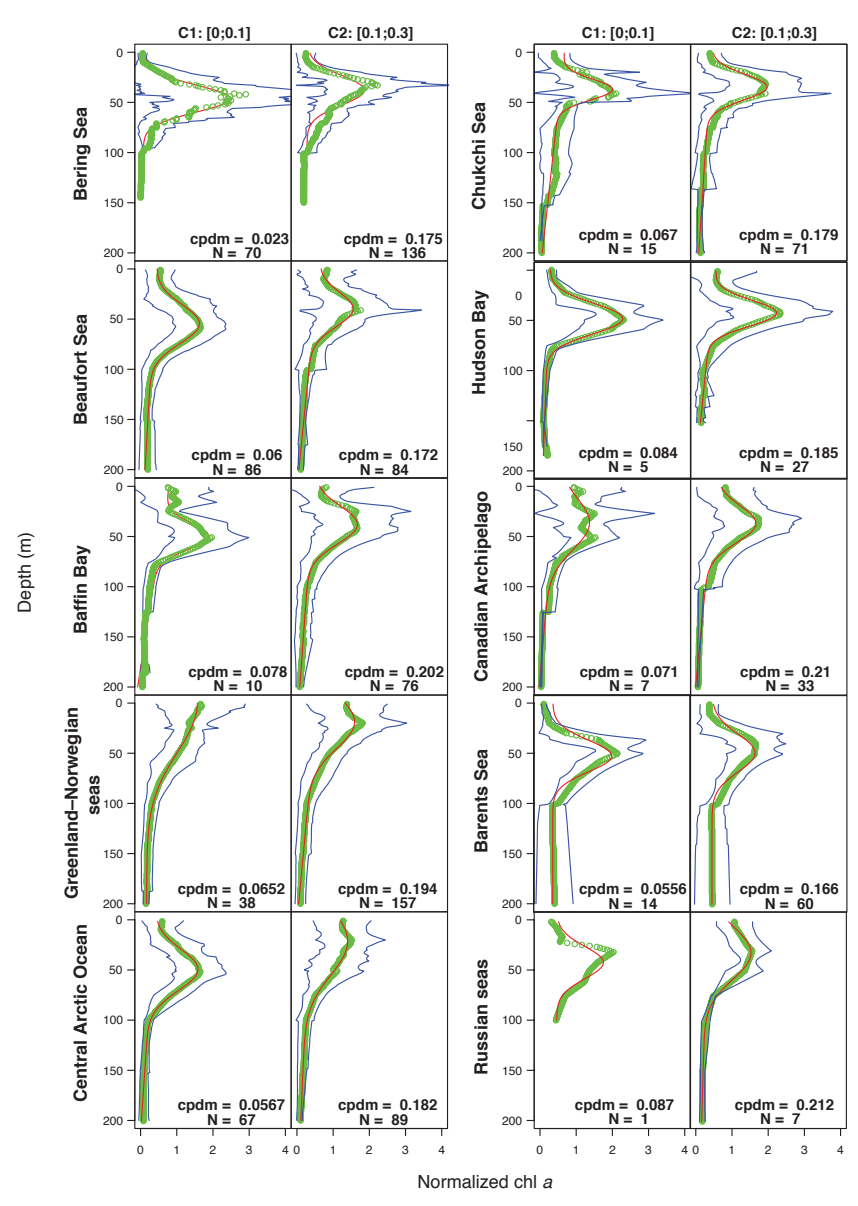

Fig. 7. Average dimensionless chlorophyll $a(\mathrm{Chl} a)$ profiles (green lines) obtained for each category $(\mathrm{C} 1-\mathrm{C} 2)$ at deep $(>50 \mathrm{~m})$ stations of each sub-Arctic and Arctic sea during the post-bloom period. Red and blue lines represent the parameterized vertical Chl $a$ profiles and standard deviation, respectively. $\mathrm{N}$ and cpdm represent the number of stations and the averaged Chl $a_{\text {surf }}$ value, respectively.

close to the surface (i.e., $20 \mathrm{~m}$ ) in the Greenland-Norwegian seas in contrast to the other Arctic seas (Fig. 7). As mentioned by Carmack and Wassmann (2006), the GreenlandNorwegian seas are strongly influenced by thermally stratified Atlantic water in contrast to the remainder of the Arctic Ocean where haline stratification prevails. Further studies need to be conducted to describe the physical processes determining these stratification regimes and explaining the fundamental differences in the vertical Chl $a$ distribution between the Greenland-Norwegian seas and the rest of the Arctic Ocean.

\subsubsection{Arctic shelves $(\leq \mathbf{5 0} \mathrm{m})$}

Not surprisingly, our results revealed significant differences between Arctic shelves and oceanic seas in terms of the vertical Chl $a$ distribution and its temporal variability. During a single time period covering the whole growing season on
Table 4. Estimated values of the five parameters of Equation 1, obtained for the average dimensionless vertical profiles of chlorophyll $a(\mathrm{C} 1-\mathrm{C} 2)$ at deep $(>50 \mathrm{~m})$ stations of each sub-Arctic and Arctic seas during the post-bloom period (May-September).

\begin{tabular}{|c|c|c|c|c|c|}
\hline $\begin{array}{l}\text { Bin } \\
\left(\mathrm{mg} \mathrm{Chl} a \mathrm{~m}^{-3}\right)\end{array}$ & $C_{\mathrm{b}}$ & $s$ & $C_{\max }$ & $Z_{\max }$ & $\Delta z$ \\
\hline \multicolumn{6}{|l|}{ Baffin Bay } \\
\hline $\mathrm{C} 1(0-0.1)$ & 0.7794 & 0.0041 & 1.2871 & 49.95 & 18.01 \\
\hline $\mathrm{C} 2(0.1-0.3)$ & 0.4757 & 0.0020 & 1.2720 & 38.48 & 26.39 \\
\hline \multicolumn{6}{|l|}{ Barents Sea } \\
\hline $\mathrm{C} 1(0-0.1)$ & 0.3675 & 0.0000 & 1.6296 & 52.75 & 22.34 \\
\hline C2 (0.1-0.3) & 0.4318 & 0.0000 & 1.1900 & 49.28 & 26.70 \\
\hline \multicolumn{6}{|l|}{ Beaufort Sea } \\
\hline $\mathrm{C} 1(0-0.1)$ & 0.4335 & 0.0015 & 1.2778 & 55.00 & 27.32 \\
\hline C2 (0.1-0.3) & 0.6024 & 0.0027 & 1.0623 & 40.47 & 24.12 \\
\hline \multicolumn{6}{|l|}{ Bering Sea } \\
\hline $\mathrm{C} 1(0-0.1)$ & 0.1134 & 0.0004 & 2.377 & 46.24 & 19.10 \\
\hline C2 (0.1-0.3) & 0.2765 & 0.0002 & 1.578 & 37.94 & 20.73 \\
\hline \multicolumn{6}{|c|}{ Canadian Archipelago } \\
\hline C1 (0-0.1) & 0.4687 & 0.0025 & 0.9920 & 37.58 & 35.92 \\
\hline $\mathrm{C} 2(0.1-0.3)$ & 0.5266 & 0.0027 & 1.2198 & 37.77 & 26.14 \\
\hline \multicolumn{6}{|c|}{ Central Arctic Ocean } \\
\hline $\mathrm{C} 1(0-0.1)$ & 0.4003 & 0.0018 & 1.2854 & 49.44 & 29.29 \\
\hline $\mathrm{C} 2(0.1-0.3)$ & 0.3260 & 0.0012 & 1.0831 & 22.67 & 45.80 \\
\hline \multicolumn{6}{|l|}{ Chukchi Sea } \\
\hline $\mathrm{C} 1(0-0.1)$ & 0.6722 & 0.0030 & 1.4435 & 37.28 & 14.64 \\
\hline C2 (0.1-0.3) & 0.4267 & 0.0018 & 1.5915 & 34.87 & 18.13 \\
\hline \multicolumn{6}{|c|}{ Greenland-Norwegian seas } \\
\hline $\mathrm{C} 1(0-0.1)$ & 0.1829 & 0.0000 & 1.3865 & 0.0000 & 69.15 \\
\hline C2 (0.1-0.3) & 0.5614 & 0.0026 & 1.0815 & 20.28 & 35.08 \\
\hline \multicolumn{6}{|l|}{ Hudson Bay } \\
\hline $\mathrm{C} 1(0-0.1)$ & 0.2807 & 0.0010 & 2.0572 & 49.60 & 21.47 \\
\hline C2 $(0.1-0.3)$ & 0.5396 & 0.0028 & 1.7995 & 42.88 & 18.19 \\
\hline \multicolumn{6}{|l|}{ Russian seas } \\
\hline $\mathrm{C} 1(0-0.1)$ & 0.4799 & 0.0000 & 1.2888 & 41.60 & 22.69 \\
\hline C2 $(0.1-0.3)$ & 0.3095 & 0.0008 & 1.2270 & 32.46 & 36.72 \\
\hline
\end{tabular}

Arctic shelves, average normalized profiles for $\mathrm{CC} 1$ to $\mathrm{CC} 2$ exhibit an increase in $\mathrm{Chl} a$ with increasing depth down to the bottom, whereas average profiles for $\mathrm{CC} 4$ to $\mathrm{CC} 7$ are relatively uniform (Fig. 8 and Table 5). In contrast, a vertical $\mathrm{Chl} a$ maximum is found at approximately $10 \mathrm{~m}$ for the highest bin of Chl $a_{\text {surf }}$ concentration (i.e., CC8) (Fig. 8).

During the pre-bloom and winter periods, the combined vertical profiles of $\mathrm{Chl} a(\mathrm{CC} 1-\mathrm{CC} 2)$ were uniform with small standard deviations throughout the profiles (Fig. 8). In contrast, strong SCMs are found close to $Z_{\mathrm{BOT}}$ during the 


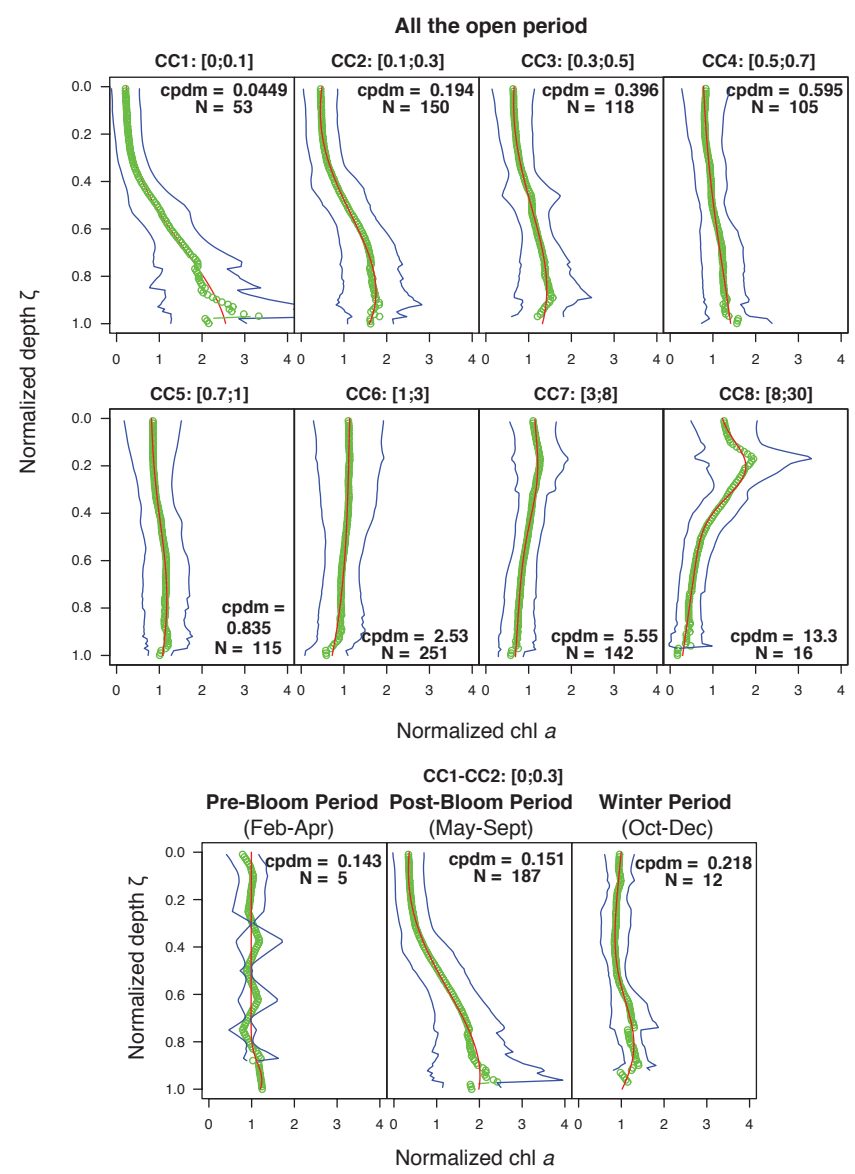

Fig. 8. Average dimensionless chlorophyll $a(\mathrm{Chl} a)$ profiles (green lines) obtained for each category $(\mathrm{CC} 1-\mathrm{CC} 8)$ during the open water period and for the combined category (CC1-CC2) of the different periods (i.e., pre-bloom, post-bloom, winter period) at shallow $(\leq 50 \mathrm{~m})$ Arctic stations. Red and blue lines represent the parameterized vertical Chl $a$ profiles and standard deviation, respectively. $\mathrm{N}$ and cpdm represent the number of stations and the averaged Chl $a_{\text {surf value, respectively. }}$

post-bloom period. This type of SCM was relatively well documented on the shelves of the Beaufort (Carmack et al., 2004; Retamal et al., 2008) and Barents (Kogeler and Rey, 1999) seas. However, the merged CC1-CC2 bin exhibits large standard deviations in Chl $a$ at all depths, which reflects the heterogeneity of physical conditions across Arctic shelves.

\subsection{Annual time series of vertical chlorophyll $a$ profiles}

All Chl $a_{\text {surf }}$ data from the different years were pooled to generate a typical annual time series for each sub-Arctic and Arctic sea, and for the Arctic shelves (i.e., Canadian, Eurasian, and Chukchi-Bering shelves; Fig. 9). Time series were smoothed using a LOESS polynomial fit. The calculated Chl $a_{\text {surf }}$ time series were then used to derive time series of the vertical Chl $a$ profile with the empirical models illus-
Table 5. Estimated values of the five parameters of Equation 1, obtained for the average dimensionless combined vertical profiles of chlorophyll $a(\mathrm{CC} 1-\mathrm{CC} 2)$ during different time periods (i.e., prebloom, post-bloom, winter) and for the average dimensionless vertical profiles of chlorophyll $a(\mathrm{CC} 1-\mathrm{CC} 8)$ during the entire period of open water at shallow $(\leq 50 \mathrm{~m})$ Arctic stations.

\begin{tabular}{lccccc}
\hline $\begin{array}{l}\text { Bin } \\
\left(\mathrm{mg} \mathrm{Chl} a \mathrm{~m}^{-3}\right)\end{array}$ & $C_{\mathrm{b}}$ & $s$ & $C_{\max }$ & $Z_{\max }$ & $\Delta z$ \\
\hline \multicolumn{7}{l}{ Entire period of open water } \\
\hline CC1 (0-0.1) & 0.0001 & 1.6112 & 4.4054 & 1.1616 & 0.6773 \\
CC2 (0.1-0.3) & 0.0001 & 2.8568 & 4.4586 & 1.0266 & 0.6895 \\
CC3 (0.3-0.5) & 0.0001 & 2.4886 & 3.8592 & 1.0916 & 0.8220 \\
CC4 (0.5-0.7) & 0.7150 & 0.0000 & 0.8592 & 1.3961 & 0.8728 \\
CC5 (0.7-1) & 0.7990 & 0.0000 & 0.3761 & 0.7589 & 0.4448 \\
CC6 (1-3) & 0.0001 & 1.4083 & 2.1591 & 1.1605 & 1.4467 \\
CC7 (3-8) & 1.0555 & 0.3629 & 0.2359 & 0.2402 & 0.2483 \\
CC8 (8-30) & 1.0796 & 0.7762 & 0.8660 & 0.2144 & 0.1637 \\
\hline Pre-bloom (February-April) & & & & \\
\hline CC1-CC2 (0-0.3) & 0.9949 & 0.0113 & 0.2550 & 0.9621 & 0.1014 \\
\hline Post-bloom (May-September) & & & & \\
\hline CC1-CC2 (0-0.3) & 0.0001 & 2.1499 & 4.1764 & 1.0666 & 0.6805 \\
\hline Winter period (October-December) & & & \\
\hline CC1-CC2 (0-0.3) & 0.9965 & 0.5444 & 0.7487 & 0.8438 & 0.2959 \\
\hline
\end{tabular}

trated in Figs. 5, 7 and 8 (red lines), using the parameters listed in Tables 3-5 (Russian seas were not considered due to data paucity; Fig. 2a). Temporal coverage was not complete for Hudson Bay and the Eurasian Shelf since the pre-bloom and winter periods are not represented in the database. The following additional limitations of the annual Chl $a_{\text {surf }}$ time series must be kept in mind: (1) the spatiotemporal bias of the dataset, and (2) the potential errors due to the inter-annual variability of the Chl $a_{\text {surf }}$ dynamics. Despite these limitations, the merged time series reveal pertinent information in terms of magnitude, shape, and dynamics of vertical Chl $a$ profiles for the different sub-Arctic and Arctic regions.

\subsubsection{Sub-Arctic and Arctic seas ( $>50 \mathrm{~m})$}

In the Greenland-Norwegian and Bering seas, the spring bloom occurs close to days of year (DOY) 117 and 137, respectively, which is relatively early compared to other regions. The spring bloom occurs slightly later in Baffin Bay (DOY 150) and, the Barents and Beaufort seas (DOY 160). The latest blooms are observed in the central Arctic Ocean (DOY 193) and Canadian Archipelago (DOY 224). The magnitude of the bloom also differs significantly among regions. The highest Chl $a_{\text {surf }}$ concentrations were recorded in the northern Bering Sea (i.e., $18 \mathrm{mg} \mathrm{m}^{-3}$ ), followed by Baffin Bay, the Canadian Archipelago, and the Chukchi and Barents seas (i.e., 6-10 $\mathrm{mg} \mathrm{m}^{-3}$ ). By contrast with these highly productive regions, the Greenland-Norwegian seas as well 

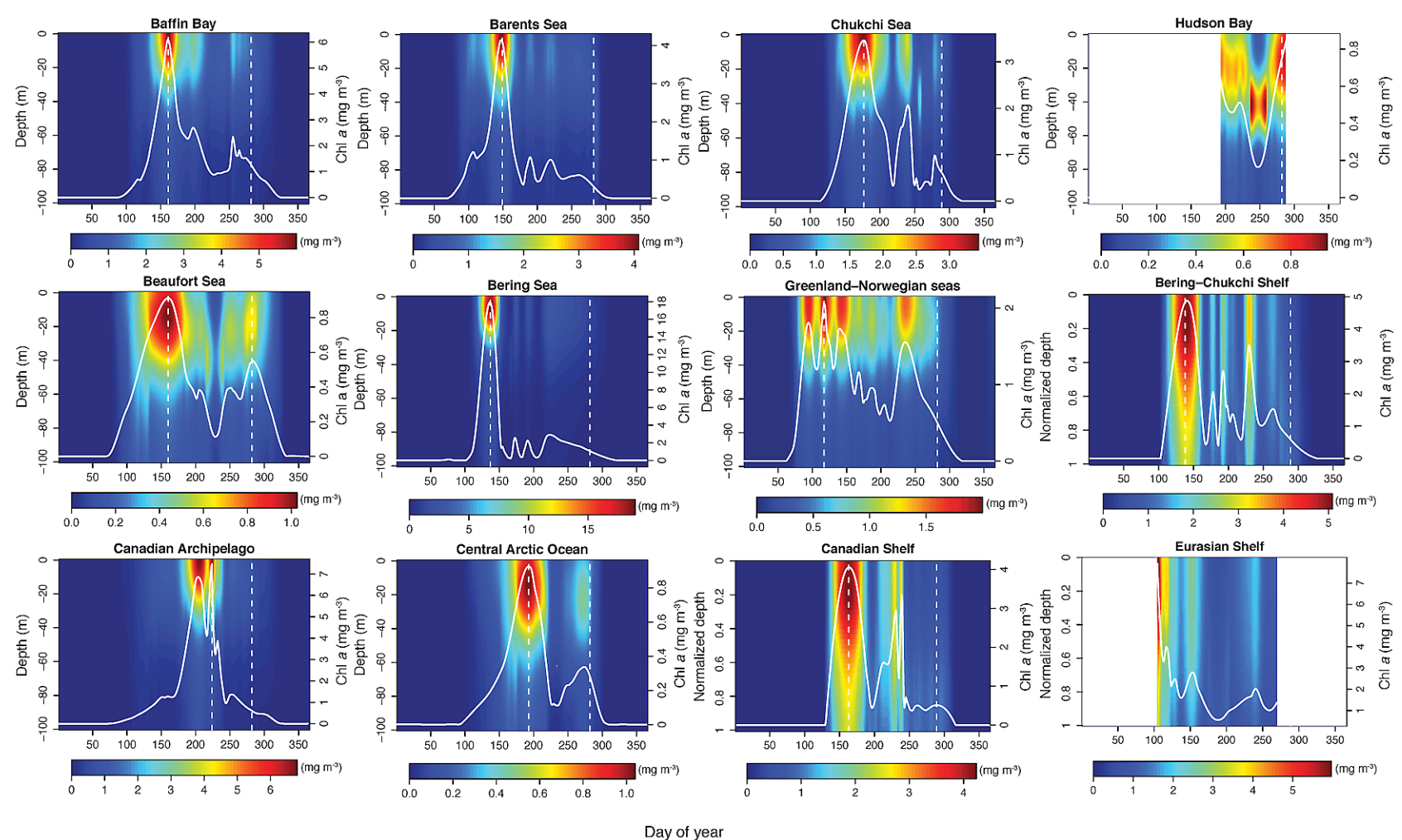

Fig. 9. Annual time series of surface chlorophyll $a$ ( $\mathrm{Chl} a_{\text {surf }}$ ) concentration combined to simulated vertical distribution of Chl $a$ using the empirical model for each sub-Arctic and Arctic sea. The two vertical dashed lines represent the two temporal delimitations, separating the pre-bloom, post-bloom, and the winter period (see Fig. 4).

as the Beaufort Sea, the central Arctic Ocean, and Hudson Bay exhibit lower $\mathrm{Chl} a_{\text {surf }}$ concentration during the bloom (i.e., $1-2 \mathrm{mg} \mathrm{m}^{-3}$ ). The magnitude and timing of the spring bloom depends mainly on winter nutrient replenishment in the upper water column, which is driven by vertical stratification, convection, and wind forcing events (Tremblay et al., 2002, 2008; Carmack et al., 2006).

A fall bloom occurs in different sub-Arctic and Arctic seas. It is observed earlier in the Greenland-Norwegian and Bering seas near DOY 200 to 230, compared with the Beaufort Sea, the Chukchi Sea, Baffin Bay, and the central Arctic Ocean, where it happens near DOY 270-300. These fall blooms generally show $\mathrm{Chl} a_{\text {surf }}$ concentrations lower than those measured during the first bloom since they occur at a time when irradiance is rapidly decreasing. Their occurrence is associated with increased vertical mixing, which results from convection (due to surface cooling and ice formation) or increased storminess. With increasing latitude or duration of the ice-covered period, incidental changes in the light regime will obviously affect annual Chl $a$ cycles and possibly timing of the ecological succession due to shorter duration of the post-bloom period and potential absence of a fall bloom, as found in the Canadian Archipelago.

The intervening period between blooms is characterized by low $\mathrm{Chl} a_{\text {surf }}$ concentrations and the potential occurrence of SCM, when the Chl $a_{\text {surf }}$ concentrations decrease below $0.5 \mathrm{mg} \mathrm{m}^{-3}$. As shown in Fig. 2f, the summer months are characterized by a significant deepening of SCM throughout the Arctic Ocean. Given their oligotrophic status, the Beaufort Sea (Carmack et al., 2004; Ardyna et al., 2011), the central Arctic Ocean (Gosselin et al., 1997; Lee and Whitledge, 2005), Hudson Bay (Harvey et al., 1997; Ferland et al., 2011), and Russian seas (Sakshaug, 2004; Hirche et al., 2006; Schmid et al., 2006) have favorable conditions for the persistence and productivity of SCM due to a rapid surface nutrient depletion at the beginning of the growing season. In the other sub-Arctic and Arctic regions, which are characterized by weakly stratified waters, episodes of SCM are more sporadic and restricted to periods of surface nutrient exhaustion. We thus argue that these seasonal features have significant implications for nitrate-based new production, food webs, and biogeochemical cycles mainly in oligotrophic regions and during limited periods of nutrient exhaustion at the surface in other sub-Arctic and Arctic seas.

\subsubsection{Arctic shelves $(\leq 50 \mathrm{~m})$}

For the three Arctic shelves (i.e., Canadian, Bering-Chukchi and Eurasian shelves), annual Chl $a_{\text {surf }}$ time series were compiled, and associated vertical $\mathrm{Chl} a$ profiles were equally 
generated using the empirical models (Fig. 9). Spring blooms are conspicuous over Arctic shelves, with an initial Chl $a_{\text {surf }}$ spike reaching up to $5-7 \mathrm{mg} \mathrm{m}^{-3}$ and subsequent, sporadic Chl $a$ bursts throughout the growing period (including the fall bloom). Intervening periods with low $\mathrm{Chl} a_{\text {surf }}$ concentrations ( $\mathrm{Chl} a<0.5 \mathrm{mg} \mathrm{m}^{-3}$ ) and the presence of SCM close to the bottom are common.

\subsection{Sensitivity of primary production models to the presence of a SCM}

To assess the potential bias attached to satellite-based estimates of depth-integrated PP when the SCM is omitted, the contribution of SCM to total water column production was quantified for each sub-Arctic and Arctic sea (Table 6). The daily PP was calculated from the different time series for each sub-Arctic and Arctic sea using two Chl $a$ profiles: (1) the modeled vertical Chl $a$ parameterization as described above, and (2) a homogenous distribution corresponding to the Chl $a_{\text {surf }}$ value applied at all depths down to $100 \mathrm{~m}$ or to $Z_{\text {Вот }}$ for the Arctic shelves (Table 6). The percentage change in depth-integrated daily primary production between the two vertical Chl $a$ profiles was also estimated (Table 6) and uncertainties on PP estimates due to misrepresentations of the modeled vertical $\mathrm{Chl} a$ profiles were investigated. The largest deviations $( \pm 20 \%)$ in depth-integrated $\mathrm{PP}$ estimates were measured during the post-bloom period (C1-C2; Fig. 7); however, they remain negligible when compared to the annual PP estimates. The recent study by Arrigo et al. (2011) showed that a homogenous Chl $a$ profile was relatively similar in terms of depth-integrated PP estimates to two other methods, which consisted in vertically extending Chl $a_{\text {surf }}$ concentration down to (1) $20 \mathrm{~m}$ and (2) $40 \mathrm{~m}$ and applying an exponential decrease underneath. However, these two methods present limitations during the post-bloom period, when a shortage of inorganic nitrogen in the upper euphotic zone induces SCM below 20 or $40 \mathrm{~m}$.

For the sub-Arctic and Arctic seas $(>50 \mathrm{~m})$, overestimations of depth-integrated PP are generally observed when assuming a uniform $\mathrm{Chl} a$ profile for the pre-bloom period $(8.2-15.4 \%)$, the winter period $(2.6-5.7 \%)$, and in the majority of regions during the post-bloom period when Chl $a>0.7 \mathrm{mg} \mathrm{m}^{-3}(0.7-7.7 \%)$ (Table 6). In all sectors of the Arctic Ocean, the largest PP overestimations clearly occur during the pre-bloom period, when surface Chl $a$ tends to be high (up to $20 \%$ at the maximum of the spring bloom; data not shown). In pre-bloom conditions, Chl $a$ exhibits a rapid exponential decrease with increasing depth, which departs from the assumption of vertical homogeneity (Fig. 5). Thereafter, the consequences of a similar shape of vertical Chl $a$ profiles during the post-bloom (when Chl $a_{\text {surf }}>0.7 \mathrm{mg} \mathrm{m}^{-3}$ ) and winter periods could explain, to a lesser degree, PP overestimations.

Conversely, a relatively large underestimation of PP is observed during the post-bloom period for $\mathrm{Chl} a<0.5 \mathrm{mg} \mathrm{m}^{-3}$
$(-8.9$ to $-22.2 \%)$ and for the range $0.5-0.7 \mathrm{mg} \mathrm{m}^{-3}(-2.3$ to $-9.5 \%$ ), due to the unaccounted presence of SCM. Because SCMs are located deeper in highly stratified and oligotrophic regions, the largest underestimations of depthintegrated PP (up to $40 \%$ for the extreme cases) during the post-bloom period are found in the Beaufort Sea, the central Arctic Ocean, and Hudson Bay (data not shown). The Russian seas (i.e., Kara, Laptev, and Siberian seas), which receive the major fraction of river discharge in the Arctic Ocean and are characterized by severe oligotrophic conditions (Carmack et al., 2006; Hirche et al., 2006; Schmid et al., 2006), are probably subjected to similar underestimations of depthintegrated PP during the post-bloom period.

On Arctic shelves $(\leq 50 \mathrm{~m})$, overestimations of depthintegrated PP are generally observed during the prebloom $(6.1-9.4 \%)$ and post-bloom $(4.7-8.4 \%)$ periods for Chl $a>0.7 \mathrm{mg} \mathrm{m}^{-3}$ (Table 6). Large underestimations of PP are also found during the post-bloom period for Chl $a<0.5 \mathrm{mg} \mathrm{m}^{-3}$ (-27.8 to $\left.-29.4 \%\right)$, in the $0.5-$ $0.7 \mathrm{mg} \mathrm{m}^{-3}$ range $(-15.0$ to $-17.5 \%)$ and to lesser extent during the winter period $(-9.1$ to $-17.8 \%)$.

When assuming a uniform Chl $a$ profile, annual PP overestimates vary between 3.7 to $10.9 \%$ of the total annual PP estimates across the different regions of the Arctic Ocean (Table 6). Given the lower contribution of the post-bloom pe$\operatorname{riod}\left(<0.7 \mathrm{mg} \mathrm{m}^{-3}\right)$ to annual PP estimates, the annual PP underestimates (i.e., 0.1 to $6.9 \%$ ) remain lower compared to annual PP overestimates except for the Beaufort Sea.

\subsection{Annual regional and pan-Arctic primary production}

\subsubsection{Sub-Arctic and Arctic seas ( $>50 \mathrm{~m}$ )}

Using our PP algorithm, the average areal PP was calculated for each sub-Arctic and Arctic sea (except the Russian seas and the entire Hudson Bay) based on the annual time series of vertical $\mathrm{Chl} a$ profiles (Table 6). The most productive regions are the Bering Sea, Baffin Bay, and the Canadian Archipelago with an annual PP of 167.8, 141.3, and $139.4 \mathrm{~g} \mathrm{C} \mathrm{m}^{-2} \mathrm{yr}^{-1}$, respectively. The level of annual PP was relatively similar in the Barents Sea, GreenlandNorwegian seas and Chukchi Sea with 104.2, 103.7, and $100.6 \mathrm{~g} \mathrm{C} \mathrm{m}^{-2} \mathrm{yr}^{-1}$, respectively. Finally, the Beaufort Sea and the central Arctic Ocean showed the lowest annual PP with 61.5 and $46.1 \mathrm{~g} \mathrm{C} \mathrm{m}^{-2} \mathrm{yr}^{-1}$, respectively. Unfortunately, PP in the Hudson Bay could only be estimated for the postbloom period when it reaches $24.7 \mathrm{~g} \mathrm{C} \mathrm{m}^{-2} \mathrm{yr}^{-1}$. Our annual PP estimates of the different sub-Arctic and Arctic seas agree with those reported by Sakshaug (2004), except for the Canadian Archipelago (see Table 6). In this study, most of the stations from the Canadian Archipelago were collected in Lancaster Sound and Hudson Strait, which are known to be highly productive areas (Michel et al., 2006; Ardyna et al., 2011; Ferland et al., 2011). This may explain the large 


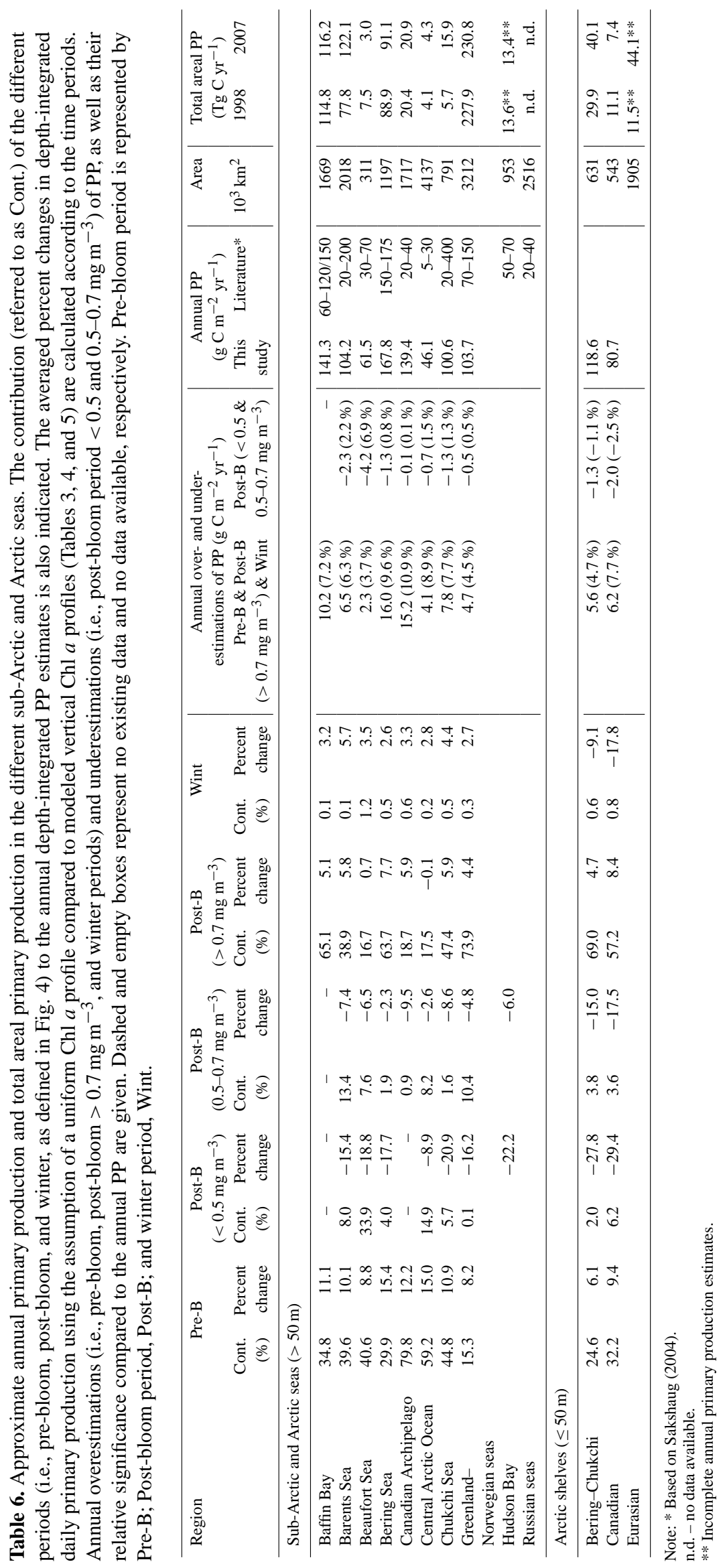


discrepancy in annual PP estimates between this study and previous ones for the Canadian Archipelago.

In the different sub-Arctic and Arctic seas, the depthintegrated PP estimates of the pre-bloom and post-bloom $\left(>0.7 \mathrm{mg} \mathrm{m}^{-3}\right.$ ) periods contribute to most of the annual depth-integrated PP (57.3-99.9\%). The depth-integrated PP estimates for the winter period represent a minor fraction of the annual PP $(0.1-1.2 \%)$ in all the sub-Arctic or Arctic seas (Table 6). The contribution of the post-bloom $\left(<0.5 \mathrm{mg} \mathrm{m}^{-3}\right)$ to annual PP, when the SCM is a prominent feature, is significant for the Beaufort Sea $(33.9 \%)$. In wellmixed waters, the post-bloom $\left(<0.5 \mathrm{mg} \mathrm{m}^{-3}\right)$ contribution to annual PP is substantially lower $(<10 \%)$. Our results agree with recent observations and show that SCM can exist in both calm and highly turbulent conditions, although, under turbulent conditions, a weakening of the SCM is evident (Wang and Goodman, 2010).

\subsubsection{Arctic shelves $(\leq \mathbf{5 0} \mathrm{m})$}

Based on the simulated annual time-series of vertical Chl $a$ profiles, depth-integrated PP was also calculated for each Arctic shelf (except the Eurasian Shelf, Table 6). The Bering-Chukchi Shelf was the most productive with an annual PP of $118.6 \mathrm{~g} \mathrm{C} \mathrm{m}^{-2} \mathrm{yr}^{-1}$, followed by the Canadian Shelf with an annual PP of $80.7 \mathrm{~g} \mathrm{C} \mathrm{m}^{-2} \mathrm{yr}^{-1}$. In terms of seasonality, the pre-bloom and post-bloom $\left(>0.7 \mathrm{mg} \mathrm{m}^{-3}\right)$ periods contributed most of the annual PP (89.4 to 93.6\%) over the Bering-Chukchi and Canadian shelves. Unfortunately, PP in the Eurasian Shelf could only be assessed using data from the post-bloom period, and the value of $97.2 \mathrm{~g} \mathrm{C} \mathrm{m}^{-2} \mathrm{yr}^{-1}$ presumably is an underestimate. Note that our annual estimates of shelf PP are still preliminary and that further studies will need to be conducted to resolve spatial and temporal complexity.

\subsubsection{Total pan-Arctic primary production}

Two annual depth-integrated PP estimates were determined for the entire Arctic Ocean with respect to a high (i.e., 1998) and a low (i.e., 2007) annual sea-ice cover (Table 6). By applying adequate atmospheric and sea-ice climatologies, daily depth-integrated PP was calculated and annually integrated for each sub-Arctic and Arctic sea, and for the Arctic shelves. Total pan-Arctic PP averaged 613 and $709 \mathrm{Tg} \mathrm{C} \mathrm{yr}^{-1}$ in 1998 and 2007, respectively. These pan-Arctic PP values are likely to be underestimates of actual rates because in situ Chl $a$ measurements are incomplete in terms of spatial coverage in Russian seas and of temporal coverage in Hudson Bay and in the Eurasian Shelf. To our knowledge, only few historical estimates of pan-Arctic primary production have been published. Despite differences in the spatial delineation of the Arctic Ocean, our pan-Arctic PP estimates are relatively similar to estimates reported by in situ studies (329-812 Tg C yr $^{-1}$; Sakshaug, 2004), remote sensing stud- ies (441 $\mathrm{Tg} \mathrm{Cyr}^{-1}$ in 1998 to $585 \mathrm{Tg} \mathrm{C} \mathrm{yr}^{-1}$ in 2007, Arrigo et al., 2011; $410 \mathrm{Tg} \mathrm{C} \mathrm{yr}^{-1}$ in 1998 to $450 \mathrm{Tg} \mathrm{C} \mathrm{yr}^{-1}$ in 2007 , Bélanger et al., 2013) and modeling studies (456 $\mathrm{Tg} \mathrm{C} \mathrm{yr}^{-1}$ in 1998 to $682 \mathrm{Tg} \mathrm{C} \mathrm{yr}^{-1}$ in 2007, Zhang et al., 2010). It is important to note, however, that the present and previously published depth-integrated PP estimates should be considered conservative due to the difficulties of assessing under-ice primary production (Mundy et al., 2009; Lee et al., 2010; Leu et al., 2011; Arrigo et al., 2012) and highly productive ice-edge blooms (Alexander and Niebauer, 1981; Gradinger and Baumann, 1991; Smith et al., 1997; Perrette et al., 2011), which are both under-documented but potentially major widespread features of the Arctic Ocean.

\section{Conclusions}

Empirical models developed for temperate and tropical oceans have proven to be useful for estimating vertical Chl $a$ profiles and for improving PP estimates based on OC (Morel and Berthon, 1989; Uitz et al., 2006; Platt et al., 2008). Based on a large in situ dataset, we proposed here a novel empirical model of the vertical Chl $a$ distribution specifically tuned for the Arctic Ocean. Our analysis reveals regional and seasonal regimes that are best addressed with specific sub-models.

Over an annual cycle, the errors in regional PP estimates caused by ignoring the vertical variations in Chl $a$ are relatively small. Also, overestimates (i.e., during pre-bloom, post-bloom for Chl $a>0.7 \mathrm{mg} \mathrm{m}^{-3}$, and the winter period) somewhat compensate partially for underestimates (i.e., during post-bloom for $\mathrm{Chl} a<0.5 \mathrm{mg} \mathrm{m}^{-3}$ ). Our results are consistent with those of Arrigo et al. (2011), showing a limited impact of SCM on annual depth-integrated PP estimates. SCMs, however, are an important seasonal feature and have a strong impact on depth-integrated PP estimates in highly stratified and oligotrophic conditions and during limited periods of time in other Arctic regions. Combining our empirical Chl $a(z)$ model with ocean color PP models may allow minimizing the error associated with the estimation of PP under stratified and oligotrophic conditions where SCMs are prevailing.

Documenting the year-to-year changes in Arctic Ocean PP is essential to understand the impact of climate change on marine ecosystems (Pabi et al., 2008; Arrigo and van Dijken, 2011), but documenting the changes in the seasonal modulation of PP is equally critical. Important seasonal events include the timing or magnitude of the spring bloom (Kahru et al., 2010), the duration of the post-bloom period and its relationship to surface nutrient exhaustion, as well as the occurrence and magnitude of a fall bloom. Furthermore, recent studies predict possible decreases of PP in the seasonal ice zone or a mismatch between primary and secondary producers, which may result in negative consequences for Arctic marine ecosystems (Søreide et al., 2010; Leu et al., 2011). Future remote sensing studies will prove important 
in assessing changes in the magnitude and seasonal distribution of PP, which are two important factors in assessing how marine Arctic ecosystems respond to multiple environmental stressors.

\section{Appendix A}

\section{Validation of the depth-integrated PP algorithm}

To our knowledge, few evaluations of depth-integrated PP algorithms have been conducted in direct comparison with in situ PP measurements in Arctic waters. Our depth-integrated PP algorithm was validated using unpublished and published PP and Chl $a$ concentration data collected in diverse regions and seasons in the Arctic Ocean (Table 2). All the PP measurements were made using the $24 \mathrm{~h}$ (or from dawn to sunset) ${ }^{14}$ C-uptake method (Knap et al., 1996; Gosselin et al., 1997), under in situ or simulated in situ conditions (i.e., light and temperature). Data from a total of 320 stations were gathered. In addition, when available, $Z_{\mathrm{EU}}$ (defined as $1 \%$ of surface irradiance) was determined to examine different parameterizations of the absorption coefficients. Several instruments were used to estimate $Z_{\mathrm{EU}}$ according to the oceanographic campaigns, as the PNF-300 (Biospherical) and SPMR/SMSR (Satlantic) in-water radiometers, and CTD rosette/PAR sensor (Biospherical QCP-2300).

Besides, a comparison between in situ and on-deck new PP measurements by ${ }^{15} \mathrm{NO}_{3}$ uptake was conducted during the Malina cruise in the Beaufort Sea. A linear regression between these two methods $\left(r^{2}=0.76\right.$; slope $\left.=1.02 ; N=32\right)$ indicates a good agreement, showing that on deck incubations do not over- or underestimate PP in the water column and at the SCM.

Throughout different areas of the Arctic Ocean (i.e. fjords, Arctic shelves and seas), five algorithms based on different parameterizations of the absorption coefficients to estimate $Z_{\mathrm{EU}}$ were tested (see Sect. 2). Results are summarized in Table A1. Interestingly, we notice two opposite results with overestimations for parameterization [5] and underestimations for parameterizations $[2,3,4]$ of $Z_{\mathrm{EU}}$. Given that parameterization [5] was developed for open-ocean (Case1) waters and is essentially governed by the phytoplankton content and related derivatives, overestimation of $Z_{\mathrm{EU}}$ was largely anticipated and demonstrates the requirement for a regional parameterization in Arctic waters. In the parameterizations [2,4], the use of Chl $a$ concentration as a predictor of $a_{\mathrm{CDOM}}(\lambda, z)$ probably results in a large overestimation of $a_{\mathrm{CDOM}}(\lambda, z)$ and an underestimation of $Z_{\mathrm{EU}}$. The surface salinity was then tested as a predictor of $a_{\mathrm{CDOM}}(\lambda, z)$ using two different parameterizations from Granskog et al. (2007) [3] and Matsuoka et al. (2012) [1]. $a_{\mathrm{CDOM}}(\lambda, z)$ values measured in the Hudson Bay system by Granskog et al. (2007) were particularly high (i.e. $a_{\mathrm{CDOM}}(355, z) \approx 3-3.5 \mathrm{~m}^{-1}$ at $25 \mathrm{PSU}$ ) resulting in an underestimation of $Z_{\mathrm{EU}}$ for our val-
Table A1. Performance indices for relative errors in algorithms for $Z_{\mathrm{EU}}$ estimates $\left(Z_{\mathrm{EU}}(\mathrm{alg})\right)$ as compared with in situ $Z_{\mathrm{EU}}$ measurements $\left(Z_{\mathrm{EU}}\right.$ (meas)).

\begin{tabular}{lccccccc}
\hline $\begin{array}{l}\text { Algo- } \\
\text { rithm }\end{array}$ & $M$ & SD & RMSE & $\begin{array}{c}\text { APD } \\
(\%)\end{array}$ & $F_{\text {med }}$ & $F_{\min }$ & $F_{\max }$ \\
\hline 1 & -0.04 & 0.16 & 0.11 & 29.93 & 0.92 & 0.63 & 1.34 \\
2 & -0.38 & 0.15 & 0.35 & 56.48 & 0.42 & 0.29 & 0.60 \\
3 & -0.55 & 0.32 & 0.89 & 65.46 & 0.28 & 0.13 & 0.60 \\
4 & -0.28 & 0.15 & 0.26 & 47.65 & 0.52 & 0.37 & 0.75 \\
5 & 0.07 & 0.26 & 0.16 & 68.25 & 1.17 & 0.64 & 2.14 \\
\hline
\end{tabular}

Note: Columns are the mean $(M)$, standard deviation (SD), root mean square error (RMSE) and absolute percent deviation (APD) of the log-difference error. The geometric mean and one-sigma range of the ratio $\left(F=Z_{\mathrm{EU}}(\operatorname{alg}) / Z_{\mathrm{EU}}\right.$ (meas) $)$ are respectively given by $F_{\mathrm{med}}, F_{\min }$, and $F_{\max }$, as defined in the Appendix A.

idation dataset. Parameterization [1] shows the best agreement with in situ measurements. Besides the parameterization of $a_{\varphi}(\lambda, z)$ and $a_{\mathrm{NAP}}(\lambda, z)$ (Matsuoka et al., 2011), the proposed parameterization of $a_{\mathrm{CDOM}}(\lambda, z)$ based on empirical relationships (Bélanger et al., 2006; Matsuoka et al., 2012) using the salinity as a predictor for CDOM absorption appears to be representative of both coastal and oceanic Arctic waters.

In the Arctic Ocean, it has been shown that phytoplankton communities are photosynthetically equipped to take advantage of the short growing season and low light levels in partially ice-covered areas and under high cloud-cover conditions (Platt et al., 1982; Gallegos et al., 1983; Harrison and Platt, 1986; Rey, 1991). More recently, it was suggested that Arctic phytoplankton are sufficiently acclimated to existing light conditions for maintaining saturated rates of carbon fixation during the course of a bloom as well as during the deepening of the SCM (Martin et al., 2010; Palmer et al., 2011). In addition, Huot et al. (2013) showed that the Beaufort Sea phytoplankton communities are more "shade acclimated" than previously reported for high-latitude regions (Arrigo and Sullivan, 1994; Arrigo et al., 1998). It is especially critical to adopt appropriate photosynthetic parameters for the performance of our depth-integrated PP algorithm, taking into account the photoacclimation/adaptation of Arctic phytoplankton communities.

To evaluate the performance of the depth-integrated PP algorithm, the log-difference error $(\Delta)$ was calculated as described in Campbell et al. (2002) and Friedrichs et al. (2009):

$\Delta=\log (\mathrm{PP})-\log \left(\mathrm{PP}_{\text {in situ }}\right)$,

where $\mathrm{PP}$ is the modeled $\mathrm{PP}$ estimate and $\mathrm{PP}_{\text {in situ }}$ $\left(\mathrm{mg} \mathrm{C} \mathrm{m}{ }^{-2} \mathrm{~d}^{-1}\right)$ represents the in situ PP measurement.

The mean $(M)$, standard deviation (SD), and root-meansquare error (RMSE) of the $320 \log$-difference errors $(\Delta)$ were examined. Since the units of these indices are decades of $\log$ and not easily translated into absolute terms, Campbell et al. (2002) proposed non-dimensional inverse-transformed 


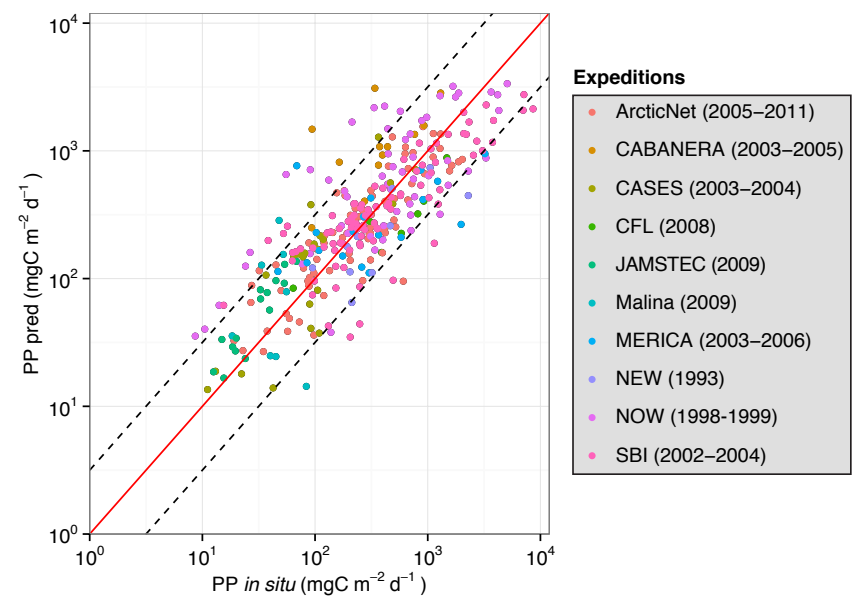

Fig. A1. Scatterplots of algorithm-derived PP versus in situ PP measurements. Solid line represents perfect agreement, and dashed lines represent factor of 2 relative errors.

values:

$F_{\text {med }}=10^{M}$,

$F_{\min }=10^{M-\mathrm{SD}}$

and

$F_{\max }=10^{M+\mathrm{SD}}$,

where $F_{\text {med }}$ is the median value of the ratio $F_{\text {med }}=\frac{\mathrm{PP}}{\mathrm{PP}_{\text {in situ }}}=$ $10^{\Delta}$ and $68 \%$ of the $F$ values would lie within the "onesigma" range ( $F_{\min }$ to $\left.F_{\max }\right)$.

Our depth-integrated PP algorithm shows good agreement with in situ data, in the range of other depth-integrated PP algorithms developed for temperate and tropical oceans $(M=$ $0.04, \mathrm{SD}=0.34, \mathrm{RMSE}=0.16, F_{\text {med }}=1.09, F_{\min }=0.49$, $F_{\max }=2.42$, Fig. A1; Friedrichs et al., 2009).

Acknowledgements. This project was supported by grants from the Canada Excellence Research Chair (CERC) in Remote Sensing of Canada's New Arctic Frontier, the Takuvik Joint International Laboratory (CNRS and Université Laval), the Canadian Network Centre of Excellence ArcticNet, the Natural Sciences and Engineering Research Council of Canada, and Québec-Océan funded by the Fonds de recherche du Québec - Nature et technologies. M. Ardyna received a postgraduate scholarship from the CERC Remote Sensing of Canada's New Arctic Frontier and stipends from ArcticNet and Québec-Océan. We gratefully acknowledge M. Benoît-Gagné, S. Çizmeli, and J. Uitz for programming assistance and precious advice; J. Sahlin for geospatial analyses; and D. ChristiansenStowe for language support. We gratefully acknowledge P. Matrai and the NOAA-NODC agencies for the availability of the ARCSS-PP database, described in detail on the website (http: //www.nodc.noaa.gov/cgi-bin/OAS/prd/accession/details/63065). We are also especially indebted to M. Blais, S. Brugel, F. Bruyant,
H. Claustre, S. Demers, J. Ferland, A. Forest, M. Granskog, Y. Gratton, H. Hodal, A. Lapoussière, J. Martin, C. Nozais, N. Price, P. Raimbault, J. Ras, M. Reigstad, M. Starr, and A. Sundfjord for sharing data. We also thank particularly A. Forest, M. H. Forget, A. Baya, T. Lacour and the whole Takuvik team for constructive comments on initial versions of the manuscript, and E. Boss and two anonymous reviewers for constructive and insightful reviews. This is a contribution to the research programs of the CERC in Remote Sensing of Canada's New Arctic Frontier, Takuvik Joint International Laboratory, ArcticNet, Institut des sciences de la mer de Rimouski, and Québec-Océan.

Edited by: E. Boss

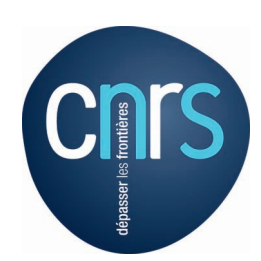

The publication of this article is financed by CNRS-INSU.

\section{References}

Alexander, V. and Niebauer, H. J.: Oceanography of the eastern Bering Sea ice-edge zone in spring, Limnol. Oceanogr., 26, 1111-1125, 1981.

Antoine, D. and Morel, A.: Oceanic primary production: 1. Adaptation of a spectral light-photosynthesis model in view of application to satellite chlorophyll observations, Global Biogeochem. Cy., 10, 43-55, 1996.

Ardyna, M., Gosselin, M., Michel, C., Poulin, M., and Tremblay, J.-É.: Environmental forcing of phytoplankton community structure and function in the Canadian High Arctic: contrasting oligotrophic and eutrophic regions, Mar. Ecol.-Prog. Ser., 442, 3757, doi:10.3354/meps09378, 2011.

Arrigo, K. R. and Sullivan, C. W.: A high resolution bio-optical model of microalgal growth: Tests using sea-ice algal community time-series data, Limnol. Oceanogr., 39, 609-631, 1994.

Arrigo, K. R. and van Dijken, G. L.: Secular trends in Arctic Ocean net primary production, J. Geophys. Res., 116, C09011, doi:10.1029/2011JC007151, 2011.

Arrigo, K. R., Worthen, D., Schnell, A., and Lizotte, M. P.: Primary production in Southern Ocean waters, J. Geophys. Res., 103, 15587-15600, doi:10.1029/98JC00930, 1998.

Arrigo, K. R., van Dijken, G., and Pabi, S.: Impact of a shrinking Arctic ice cover on marine primary production, Geophys. Res. Lett., 35, L19603, doi:10.1029/2008g1035028, 2008.

Arrigo, K. R., Matrai, P. A., and van Dijken, G. L.: Primary productivity in the Arctic Ocean: Impacts of complex optical properties and subsurface chlorophyll maxima on large-scale estimates, J. Geophys. Res., 116, C11022, doi:10.1029/2011JC007273, 2011.

Arrigo, K. R., Perovich, D. K., Pickart, R. S., Brown, Z. W., van Dijken, G. L., Lowry, K. E., Mills, M. M., Palmer, M. A., Balch, W. M., Bahr, F., Bates, N. R., Benitez-Nelson, C., Bowler, B., Brownlee, E., Ehn, J. K., Frey, K. E., Garley, R., Laney, S. R., Lubelczyk, L., Mathis, J., Matsuoka, A., Mitchell, B. G., Moore, G. W. K., Ortega-Retuerta, E., Pal, S., Polashenski, C. M., Reynolds, R. A., Schieber, B., Sosik, H. M., Stephens, M., 
and Swift, J. H.: Massive phytoplankton blooms under Arctic sea ice, Science, 336, 1408, doi:10.1126/science.1215065, 2012.

Babin, M., Stramski, D., Ferrari, G. M., Claustre, H., Bricaud, A., Obolensky, G., and Hoepffner, N.: Variations in the light absorption coefficients of phytoplankton, nonalgal particles, and dissolved organic matter in coastal waters around Europe, J. Geophys. Res., 108, 3211, doi:10.1029/2001JC000882, 2003.

Bates, D. M. and Watts, D. G.: Nonlinear Regression Analysis and Its Applications, John Wiley \& Sons, 2007.

Behrenfeld, M. J., O’Malley, R. T., Siegel, D. A., McClain, C. R., Sarmiento, J. L., Feldman, G. C., Milligan, A. J., Falkowski, P. G., Letelier, R. M., and Boss, E. S.: Climate-driven trends in contemporary ocean productivity, Nature, 444, 752-755, doi:10.1038/nature05317, 2006.

Bélanger, S., Xie, H., Krotkov, N., Larouche, P., Vincent, W. F., and Babin, M.: Photomineralization of terrigenous dissolved organic matter in Arctic coastal waters from 1979 to 2003: Interannual variability and implications of climate change, Global Biogeochem. Cy., 20, GB4005, doi:10.1029/2006GB002708, 2006.

Bélanger, S., Babin, M., and Tremblay, J.-É.: Increasing cloudiness in Arctic damps the increase in phytoplankton primary production due to sea ice receding, Biogeosciences, 10, 4087-4101, doi:10.5194/bg-10-4087-2013, 2013.

Bricaud, A., Babin, M., Morel, A., and Claustre, H.: Variability in the chlorophyll-specific absorption coefficients of natural phytoplankton: Analysis and parameterization, J. Geophys. Res., 100, 13321-13332, doi:10.1029/95JC00463, 1995.

Brugel, S., Nozais, C., Poulin, M., Tremblay, J.-É., Miller, L. A., Simpson, K. G., Gratton, Y., and Demers, S.: Phytoplankton biomass and production in the southeastern Beaufort Sea in autumn 2002 and 2003, Mar. Ecol.-Prog. Ser., 377, 63-77, doi:10.3354/meps07808, 2009.

Cai, W. J., Chen, L., Chen, B., Gao, Z., Lee, S. H, Chen, J., Pierrot, D., Sullivan, K., Wang, Y., Hu, X., Huang, W.-J., Zhang, Y., Xu, S., Murata, A., Grebmeier, J. M., Jones, E. P., and Zhang, H.: Decrease in the $\mathrm{CO}_{2}$ uptake capacity in an ice-free Arctic Ocean basin, Science, 329, 556-559, doi:10.1126/science.1189338, 2010.

Campbell, J., Antoine, D., Armstrong, R., Arrigo, K., Balch, W., Barber, R., Behrenfeld, M., Bidigare, R., Bishop, J., Carr, M.-E., Esaias, W., Falkowski, P., Hoepffner, N., Iverson, R., Kiefer, D., Lohrenz, S., Marra, J., Morel, A., Ryan, J., Vedernikov, V., Waters, K., Yentsch, C., and Yoder, J.: Comparison of algorithms for estimating ocean primary production from surface chlorophyll, temperature, and irradiance, Global Biogeochem. Cy., 16, 1035, doi:10.1029/2001GB001444, 2002.

Carmack, E. C.: The alpha/beta ocean distinction: A perspective on freshwater fluxes, convection, nutrients and productivity in high-latitude seas, Deep-Sea Res. Pt. II, 54, 2578-2598, doi:10.1016/j.dsr2.2007.08.018, 2007.

Carmack, E. and Wassmann, P.: Food webs and physicalbiological coupling on pan-Arctic shelves: Unifying concepts and comprehensive perspectives, Prog. Oceanogr., 71, 446-477, doi:10.1016/j.pocean.2006.10.004, 2006.

Carmack, E. C., Macdonald, R. W., and Jasper, S.: Phytoplankton productivity on the Canadian Shelf of the Beaufort Sea, Mar. Ecol.-Prog. Ser., 277, 37-50, 2004.

Carmack, E., Barber, D., Christensen, J., Macdonald, R., Rudels, B., and Sakshaug, E.: Climate variability and physical forcing of the food webs and the carbon budget on panarctic shelves, Prog. Oceanogr., 71, 145-181, doi:10.1016/j.pocean.2006.10.005, 2006.

Cullen, J. J.: The deep chlorophyll maximum: Comparing vertical profiles of chlorophyll $a$, Can. J. Fish. Aquat. Sci., 39, 791-803, 1982.

Estrada, R., Harvey, M., Gosselin, M., Starr, M., Galbraith, P. S., and Straneo, F.: Late-summer zooplankton community structure, abundance, and distribution in the Hudson Bay system (Canada) and their relationships with environmental conditions, 2003-2006, Prog. Oceanogr., 101, 121-145, doi:10.1016/j.pocean.2012.02.003, 2012.

Ferland, J., Gosselin, M., and Starr, M.: Environmental control of summer primary production in the Hudson Bay system: The role of stratification, J. Mar. Syst., 88, 385-400, doi:10.1016/j.jmarsys.2011.03.015, 2011.

Friedrichs, M. A. M., Carr, M.-E., Barber, R. T., Scardi, M., Antoine, D., Armstrong, R. A., Asanuma, I., Behrenfeld, M. J., Buitenhuis, E. T., Chai, F., Christian, J. R., Ciotti, A. M., Doney, S. C., Dowell, M., Dunne, J., Gentili, B., Gregg, W., Hoepffner, N., Ishizaka, J., Kameda, T., Lima, I., Marra, J., Mélin, F. d. r., Moore, J. K., Morel, A., O’Malley, R. T., O’Reilly, J., Saba, V. S., Schmeltz, M., Smyth, T. J., Tjiputra, J., Waters, K., Westberry, T. K., and Winguth, A.: Assessing the uncertainties of model estimates of primary productivity in the tropical Pacific Ocean, J. Mar. Syst., 76, 113-133, doi:10.1016/j.jmarsys.2008.05.010, 2009.

Frolov, S., Ryan, J. P., and Chavez, F. P.: Predicting euphoticdepth-integrated chlorophyll-a from discrete-depth and satelliteobservable chlorophyll-a off central California, J. Geophys. Res., 117, C05042, doi:10.1029/2011JC007322, 2012.

Gallegos, C. L., Platt, T., Harrison, W. G., and Irwin, B.: Photosynthetic parameters of Arctic marine phytoplankton: Vertical variations and time scales of adaptation, Limnol. Oceanogr., 28, 698708, 1983.

Gradinger, R. R. and Baumann, M. E. M.: Distribution of phytoplankton communities in relation to the large-scale hydrographical regime in the Fram Strait, Mar. Biol., 111, 311-321, 1991.

Granskog, M. A., Macdonald, R. W., Mundy, C. J., and Barber, D. G.: Distribution, characteristics and potential impacts of chromophoric dissolved organic matter (CDOM) in Hudson Strait and Hudson Bay, Canada, Cont. Shelf Res., 27, 2032-2050, doi:10.1016/j.csr.2007.05.001, 2007.

Grebmeier, J. M., Smith, W. O. J., and Conover, R. J.: Biological processes on arctic continental shelves: ice-ocean biotic interactions, Arctic Oceanography: Marginal Ice Zones and Continental Shelves, edited by: Smith, W. O. J. and Grebmeier, J. M., American Geophysical Union, Washington, 231-261, 1995.

Gosselin, M., Levasseur, M., Wheeler, P. A., Horner, R. A., and Booth, B. C.: New measurements of phytoplankton and ice algal production in the Arctic Ocean, Deep-Sea Res. Pt. II, 44, 16231644, doi:10.1016/S0967-0645(97)00054-4, 1997.

Harrison, W. G. and Cota, G. F.: Primary production in polar waters: relation to nutrient availability, Polar Res., 10, 87-104, doi:10.1111/j.1751-8369.1991.tb00637.x, 1991.

Harrison, W. G. and Platt, T.: Photosynthesis-irradiance relationships in polar and temperate phytoplankton populations, Polar Biol., 5, 153-164, doi:10.1007/BF00441695, 1986. 
Harvey, M., Therriault, J. C., and Simard, N.: Late-summer distribution of phytoplankton in relation to water mass characteristics in Hudson Bay and Hudson Strait (Canada), Can. J. Fish. Aquat. Sci., 54, 1937-1952, doi:10.1139/f97-099, 1997.

Hill, V., Cota, G., and Stockwell, D.: Spring and summer phytoplankton communities in the Chukchi and Eastern Beaufort Seas, Deep-Sea Res. Pt. II, 52, 3369-3385, doi:10.1016/j.dsr2.2005.10.010, 2005.

Hill, V. J., Matrai, P. A., Olson, E., Suttles, S., Steele, M., Codispoti, L. A., and Zimmerman, R. C.: Synthesis of integrated primary production in the Arctic Ocean: II. In situ and remotely sensed estimates, Prog. Oceanogr., 110, 107-125, doi:10.1016/j.pocean.2012.11.005, 2013.

Hirche, H. J., Kosobokova, K. N., Gaye-Haake, B., Harms, I., Meon, B., and Nöthig, E.-M.: Structure and function of contemporary food webs on Arctic shelves: A panarctic comparison: The pelagic system of the Kara Sea - Communities and components of carbon flow, Prog. Oceanogr., 71, 288-313, doi:10.1016/j.pocean.2006.09.010, 2006.

Hodal, H. and Kristiansen, S.: The importance of small-celled phytoplankton in spring blooms at the marginal ice zone in the northern Barents Sea, Deep-Sea Res. Pt. II, 55, 2176-2185, doi:10.1016/j.dsr2.2008.05.012, 2008.

Huot, Y., Babin, M., and Bruyant, F.: Photosynthetic parameters in the Beaufort Sea in relation to the phytoplankton community structure, Biogeosciences, 10, 3445-3454, doi:10.5194/bg10-3445-2013, 2013.

Jerlov, N. G. (Ed.): Optical oceanography, Elsevier Oceanography Series, Elsevier, Amsterdam-London-New York, 194 pp., 1968.

Kahru, M., Brotas, V., Manzano-Sarabio, M., and Mitchell, B. G.: Are phytoplankton blooms occurring earlier in the Arctic?, Glob. Change Biol., 17, 1733-1739, doi:10.1111/j.13652486.2010.02312.x, 2010.

Klein, B., LeBlanc, B., Mei, Z. P., Beret, R., Michaud, J., Mundy, C. J., von Quillfeldt, C. H., Garneau, M. E., Roy, S., Gratton, Y., Cochran, J. K., Bélanger, S., Larouche, P., Pakulski, J. D., Rivkin, R. B., and Legendre, L.: Phytoplankton biomass, production and potential export in the North Water, Deep-Sea Res. Pt. II, 49, 4983-5002, doi:10.1016/S0967-0645(02)00174-1, 2002.

Knap, A., Micheals, A., Close, A., Ducklow, H., and Dickson, A.: Protocols for the Joint Global Ocean Flux (JGOFS) Core measurements Report no. 19, IOC Manuals and guides, UNESCO, 29, 1996.

Kogeler, J. and Rey, F.: Ocean colour and the spatial and seasonal distribution of phytoplankton in the Barents Sea, Int. J. Remote Sens., 20, 1303-1318, doi:10.1080/014311699212740, 1999.

Lansard, B., Mucci, A., Miller, L. A., Macdonald, R. W., and Gratton, Y.: Seasonal variability of water mass distribution in the southeastern Beaufort Sea determined by total alkalinity and $\delta 18 \mathrm{O}$, J. Geophys. Res., 117, C03003, doi:10.1029/2011JC007299, 2012.

Lapoussière, A., Michel, C., Gosselin, M., Poulin, M., Martin, J., and Tremblay, J.-É.: Primary production and sinking export during fall in the Hudson Bay system, Canada, Cont. Shelf Res., 52, 62-72, doi:10.1016/j.csr.2012.10.013, 2013.

Lee, S., Stockwell, D., and Whitledge, T.: Uptake rates of dissolved inorganic carbon and nitrogen by under-ice phytoplankton in the Canada Basin in summer 2005, Polar Biol., 33, 1027-1036, doi:10.1007/s00300-010-0781-4, 2010.
Lee, S. H. and Whitledge, T. R.: Primary and new production in the deep Canada Basin during summer 2002, Polar Biol., 28, 190197, doi:10.1007/s00300-004-0676-3, 2005.

Lee, Z.-P., Darecki, M., Carder, K. L., Davis, C. O., Stramski, D., and Rhea, W. J.: Diffuse attenuation coefficient of downwelling irradiance: An evaluation of remote sensing methods, J. Geophys. Res., 110, C02017, doi:10.1029/2004JC002573, 2005.

Leu, E., Søreide, J. E., Hessen, D. O., Falk-Petersen, S., and Berge, J.: Consequences of changing sea-ice cover for primary and secondary producers in the European Arctic shelf seas: Timing, quantity, and quality, Prog. Oceanogr., 90, 18-32, doi:10.1016/j.pocean.2011.02.004, 2011.

Lewis, M. R., Cullen, J. J., and Platt, T.: Phytoplankton and thermal structure in the upper ocean: Consequences of nonuniformity in chlorophyll profile, J. Geophys. Res., 88, 2565-2570, doi:10.1029/JC088iC04p02565, 1983.

Li, W. K. W., McLaughlin, F.A., Lovejoy, C., and Carmack, E. C.: Smallest algae thrive as the Arctic Ocean freshens, Science, 326, 539, doi:10.1126/science.1179798, 2009.

Longhurst, A., Sathyendranath, S., Platt, T., and Caverhill, C.: An estimate of global primary production in the ocean from satellite radiometer data, J. Plankton Res., 17, 1245-1271, doi:10.1093/plankt/17.6.1245, 1995.

Martin, J., Tremblay, J., Gagnon, J., Tremblay, G., Lapoussière, A., Jose, C., Poulin, M., Gosselin, M., Gratton, Y., and Michel, C.: Prevalence, structure and properties of subsurface chlorophyll maxima in Canadian Arctic waters, Mar. Ecol.-Prog. Ser., 412, 69-84, doi:10.3354/meps08666, 2010.

Matrai, P. A., Olson, E., Suttles, S., Hill, V., Codispoti, L. A., Light, B., and Steele, M.: Synthesis of primary production in the Arctic Ocean: I. Surface waters, 1954-2007, Prog. Oceanogr., 110, 93 106, doi:10.1016/j.pocean.2012.11.004, 2013.

Matsuoka, A., Hill, V., Huot, Y., Babin, M., and Bricaud, A.: Seasonal variability in the light absorption properties of western Arctic waters: Parameterization of the individual components of absorption for ocean color applications, J. Geophys. Res., 116, C02007, doi:10.1029/2009JC005594, 2011.

Matsuoka, A., Bricaud, A., Benner, R., Para, J., Sempéré, R., Prieur, L., Bélanger, S., and Babin, M.: Tracing the transport of colored dissolved organic matter in water masses of the Southern Beaufort Sea: relationship with hydrographic characteristics, Biogeosciences, 9, 925-940, doi:10.5194/bg-9-925-2012, 2012.

McLaughlin, F. A. and Carmack, E. C.: Deepening of the nutricline and chlorophyll maximum in the Canada Basin interior, 2003-2009, Geophys. Res. Lett., 37, L24602, doi:10.1029/2010GL045459, 2010.

Michel, C., Ingram, R. G., and Harris, L. R.: Variability in oceanographic and ecological processes in the Canadian Arctic Archipelago, Prog. Oceanogr., 71, 379-401, doi:10.1016/j.pocean.2006.09.006, 2006.

Morel, A. and Berthon, J.-F.: Surface pigments, algal biomass profiles, and potential production of the euphotic layer: Relationships reinvestigated in view of remote-sensing applications, Limnol. Oceanogr., 34, 1545-1562, 1989.

Morel, A. and Maritorena, S.: Bio-optical properties of oceanic waters: A reappraisal, J. Geophys. Res., 106, 7163-7180, doi:10.1029/2000JC000319, 2001.

Mundy, C. J., Gosselin, M., Ehn, J., Gratton, Y., Rossnagel, A., Barber, D. G., Martin, J., Tremblay, J.-É., Palmer, M., Arrigo, K. R., 
Darnis, G., Fortier, L., Else, B., and Papakyriakou, T.: Contribution of under-ice primary production to an ice-edge upwelling phytoplankton bloom in the Canadian Beaufort Sea, Geophys. Res. Lett., 36, L17601, doi:10.1029/2009GL038837, 2009.

Nishino, S., Kikuchi, T., Yamamoto-Kawai, M., Kawaguchi, Y., Hirawake, T., and Itoh, M.: Enhancement/reduction of biological pump depends on ocean circulation in the sea-ice reduction regions of the Arctic Ocean, J. Oceanogr., 67, 305-314, doi:10.1007/s10872-011-0030-7, 2011a.

Nishino, S., Itoh, M., Kawaguchi, Y., Kikuchi, T., and Aoyama, M.: Impact of an unusually large warm-core eddy on distributions of nutrients and phytoplankton in the southwestern Canada Basin during late summer/early fall 2010, Geophys. Res. Lett., 38, L16602, doi:10.1029/2011GL047885, 2011 b.

Pabi, S., van Dijken, G. L., and Arrigo, K. R.: Primary production in the Arctic Ocean, 1998-2006, J. Geophys. Res., 113, C08005, doi:10.1029/2007JC004578, 2008.

Palmer, M., Arrigo, K., Mundy, C., Ehn, J., Gosselin, M., Barber, D., Martin, J., Alou, E., Roy, S., and Tremblay, J.-É.: Spatial and temporal variation of photosynthetic parameters in natural phytoplankton assemblages in the Beaufort Sea, Canadian Arctic, Polar Biol., 34, 1915-1928, doi:10.1007/s00300-011-1050-x, 2011.

Perrette, M., Yool, A., Quartly, G. D., and Popova, E. E.: Nearubiquity of ice-edge blooms in the Arctic, Biogeosciences, 7, 515-524, doi:10.5194/bg-8-515-2011, 2011.

Pesant, S., Legendre, L., Gosselin, M., Smith, R. E. H., Kattner, G., and Ramseier, R. O.: Size-differential regimes of phytoplankton production in the northeast water Polynya $\left(77^{\circ}-81^{\circ} \mathrm{N}\right)$, Mar. Ecol.-Prog. Ser., 142, 75-86, 1996.

Platt, T., Harrison, W. G., Irwin, B., Horne, E. P., and Gallegos, C. L.: Photosynthesis and photoadaptation of marine phytoplankton in the arctic, Deep Sea Res. Pt. I, 29, 1159-1170, doi:10.1016/0198-0149(82)90087-5, 1982.

Platt, T., Sathyendranath, S., Caverhill, C. M., Lewis, M. R: Ocean primary production and available light: further algorithms for remote sensing, Deep-Sea Res. Pt. I, 35, 855-879, doi:10.1016/0198-0149(88)90064-7, 1988.

Platt, T., Sathyendranath, S., Forget, M.-H., White Iii, G. N., Caverhill, C., Bouman, H., Devred, E., and Son, S.: Operational estimation of primary production at large geographical scales, Remote Sens. Environ., 112, 3437-3448, doi:10.1016/j.rse.2007.11.018, 2008.

Pope, R. M. and Fry, E. S.: Absorption spectrum (380-700 nm) of pure water. II. Integrating cavity measurements, Appl. Opt., 36, 8710-8723, doi:10.1364/AO.36.008710, 1997.

Regaudie-de-Gioux, A. and Duarte, C. M.: Compensation irradiance for planktonic community metabolism in the ocean, Global Biogeochem. Cy., 24, GB4013, doi:10.1029/2009gb003639, 2010.

Retamal, L., Bonilla, S., and Vincent, W.: Optical gradients and phytoplankton production in the Mackenzie River and the coastal Beaufort Sea, Polar Biol., 31, 363-379, doi:10.1007/s00300007-0365-0, 2008.

Rey, F.: Photosynthetic-irradiance relationships in natural phytoplankton populations of the Barents Sea, Polar Res., 10, 105116, 1991.

Rey, F. and Loeng, H.: The influence of ice and hydrographic conditions on the development of phytoplankton in the Barents Sea, in: Marine biology of polar regions and effects of stress on marine organisms, edited by: Gray, J. S. and Christiansen, M. E., John Wiley and Sons, 49-64, 1985.

Reynolds, R. A., Stramski, D., and Mitchell, B. G.: A chlorophylldependent semianalytical reflectance model derived from field measurements of absorption and backscattering coefficients within the Southern Ocean, J. Geophys. Res., 106, 7125-7138, doi:10.1029/1999JC000311, 2001.

Ricchiazzi, P., Yang, S. R., Gautier, C., and Sowle, D.: SBDART: a research and teaching software tool for plane-parallel radiative transfer in the Earth's atmosphere, B. Am. Meteorol. Soc., 79, 2101-2114, 1998.

Rysgaard, S. R., Nielsen, T. G., and Hansen, B. W.: Seasonal variation in nutrients, pelagic primary production and grazing in a high-Arctic coastal marine ecosystem, Young Sound, Northeast Greenland, Mar. Ecol.-Prog. Ser., 179, 13-25, doi:10.3354/meps179013, 1999.

Sakshaug, E.: Primary and secondary production in the Arctic Sea, in: The Organic Carbon Cycle in the Arctic Ocean, edited by: Stein, R. and MacDonald, R. W., Springer, Berlin, 57-81, 2004.

Sallon, A., Michel, C., and Gosselin, M.: Summertime primary production and carbon export in the southeastern Beaufort Sea during the low ice year of 2008, Polar Biol., 34, 1989-2005, doi:10.1007/s00300-011-1055-5, 2011.

Schmid, M. K., Piepenburg, D., Golikov, A. A., Juterzenka, K., Petryashov, V. V., and Spindler, M.: Trophic pathways and carbon flux patterns in the Laptev Sea, Prog. Oceanogr., 71, 314 330, doi:10.1016/j.pocean.2006.09.002, 2006.

Scott, B. E., Sharples, J., Ross, O. N., Wang, J., Pierce, G. J., and Camphuysen, C. J.: Sub-surface hotspots in shallow seas: finescale limited locations of top predator foraging habitat indicated by tidal mixing and sub-surface chlorophyll, Mar. Ecol.-Prog. Ser., 408, 207-226, doi:10.3354/meps08552, 2010.

Smith, W., Gosselin, M., Legendre, L., Wallace, D., Daly, K., and Kattner, G.: New production in the Northeast Water Polynya: 1993, J. Mar. Syst., 10, 199-209, doi:10.1016/S09247963(96)00067-X, 1997.

Søreide, J. E., Leu, E. V. A., Berge, J., Graeve, M., and Falk-Petersen, S.: Timing of blooms, algal food quality and Calanus glacialis reproduction and growth in a changing Arctic, Glob. Change Biol., 16, 3154-3163, doi:10.1111/j.13652486.2010.02175.x, 2010.

Spalding, M. D., Fox, H. E., Halpern, B. S., McManus, M. A., Molnar, J., Allen, G. R., Davidson, N., Jorge, Z. A., Lombana, A. L., Lourie, S. A., Martin, K. D., McManus, E., Molnar, J., Recchia, C. A., and Robertson, J.: Marine ecoregions of the world: A bioregionalization of coastal and shelf areas, BioScience, 57, 573-583, 2007.

Tremblay, G., Belzile, C., Gosselin, M., Poulin, M., Roy, S., and Tremblay, J.-É.: Late summer phytoplankton distribution along a $3500 \mathrm{~km}$ transect in Canadian Arctic waters: strong numerical dominance by picoeukaryotes, Aquat. Microb. Ecol., 54, 55-70, doi:10.3354/ame01257, 2009.

Tremblay, J.-É., Gratton, Y., Fauchot, J., and Price, N. M.: Climatic and oceanic forcing of new, net, and diatom production in the North Water, Deep-Sea Res. Pt. II, 49, 4927-4946, doi:10.1016/S0967-0645(02)00171-6, 2002.

Tremblay, J.-É., Michel, C., Hobson, K. A., Gosselin, M., and Price, N. M.: Bloom dynamics in early opening waters of the Arctic Ocean, Limnol. Oceanogr., 51, 900-912, 
doi:10.4319/lo.2006.51.2.0900, 2006.

Tremblay, J.-É., Simpson, K., Martin, J., Miller, L., Gratton, Y., Barber, D., and Price, N. M.: Vertical stability and the annual dynamics of nutrients and chlorophyll fluorescence in the coastal, southeast Beaufort Sea, J. Geophys. Res., 113, C07S90, doi:10.1029/2007JC004547, 2008.

Tremblay, J.-É., Robert, D., Varela, D., Lovejoy, C., Darnis, G., Nelson, R., and Sastri, A.: Current state and trends in Canadian Arctic marine ecosystems: I. Primary production, Clim. Chang., 115, 161-178, doi:10.1007/s10584-012-0496-3, 2012.

Uitz, J., Claustre, H., Morel, A., and Hooker, S. B.: Vertical distribution of phytoplankton communities in open ocean: An assessment based on surface chlorophyll, J. Geophys. Res., 111, C08005, doi:10.1029/2005JC003207, 2006.

Vedernikov, V. I., Demidov, A. B., and Sud'bin, A. I.: Primary production and chlorophyll in the Kara Sea in September 1993, Oceanology Engl. Transl., 34, 693-703, 1995.

Vedernikov, V. I., Gagarin, V. I., and Burenkov, V. I.: Features of distribution of primary production and chlorophyll in the Pechora Sea in August-September 1998, Oceanology, 41, 64-74, 2001.

Vetrov, A. A. and Romankevich, E. A.: Production of phytoplankton in the Arctic Seas and its response on recent warming, Influence of Climate Change on the Changing Arctic and Sub-Arctic Conditions, edited by: Nihoul, J. C. J. and Kostianoy, A. G., NATO Science for Peace and Security Series C: Environmental Security, Springer Netherlands, 95-108, 2009.
Wang, J., Cota, G. F., and Ruble, D. A.: Absorption and backscattering in the Beaufort and Chukchi Seas, J. Geophys. Res., 110, C04014, doi:10.1029/2002JC001653, 2005.

Wang, Z. and Goodman, L.: The evolution of a thin phytoplankton layer in strong turbulence, Cont. Shelf Res., 30, 104-118, doi:10.1016/j.csr.2009.08.006, 2010.

Wassmann, P. and Reigstad, M.: Future Arctic Ocean seasonal ice zones and implications for pelagic-benthic coupling, Oceanography, 24, 220-231, doi:10.5670/oceanog.2011.74, 2011.

Wassmann, P., Duarte, C. M., Agustí, S., and Sejr, M. K.: Footprints of climate change in the Arctic marine ecosystem, Glob. Change Biol., 17, 1235-1249, doi:10.1111/j.1365-2486.2010.02311.x, 2011.

Weston, K., Fernand, L., Mills, D. K., Delahunty, R., and Brown, J.: Primary production in the deep chlorophyll maximum of the central North Sea, J. Plankton Res., 27, 909-922, 2005.

Zhang, J., Spitz, Y. H., Steele, M., Ashjian, C., Campbell, R., Berline, L., and Matrai, P.: Modeling the impact of declining sea ice on the Arctic marine planktonic ecosystem, J. Geophys. Res., 115, C10015, doi:10.1029/2009JC005387, 2010.

Zhang, X., Walsh, J. E., Zhang, J., Bhatt, U. S., and Ikeda, M.: Climatology and interannual variability of Arctic cyclone activity: 1984-2002, J. Climate, 17, 2300-2317, doi:10.1175/15200442(2004)017<2300:CAIVOA > 2.0.CO;2, 2004. 